\title{
Air Quality Improvement from COVID-19 Lockdown in the East African Community: Evidences from Kampala and Nairobi Cities
}

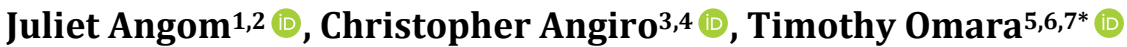 \\ ${ }^{1}$ Department of Management, Amrita Vishwa Vidyapeetham, AIMS Campus, Amrita Lane AIMS Ponekkara, Kochi, Kerala, India \\ ${ }^{2}$ Bureau of Integrated Rural Development, Kwame Nkrumah University of Science and Technology (KNUST), Kumasi, Ghana \\ ${ }^{3}$ Department of Chemistry, Faculty of Science, Kyambogo University, Kampala, Uganda \\ ${ }^{4}$ National Livestock Resources Research Institute, National Agricultural Research Organization, Kampala, Uganda \\ ${ }^{5}$ Department of Chemistry and Biochemistry, School of Sciences and Aerospace Studies, Moi University, Eldoret, Kenya \\ ${ }^{6}$ Africa Center of Excellence II in Phytochemicals, Textiles and Renewable Energy (ACE II PTRE), Moi University, Eldoret, Kenya \\ ${ }^{7}$ Department of Quality Control and Quality Assurance, AgroWays Uganda Limited, Jinja, Uganda \\ Email: *prof.timo2018@gmail.com
}

How to cite this paper: Angom, J., Angiro, C. and Omara, T. (2021) Air Quality Improvement from COVID-19 Lockdown in the East African Community: Evidences from Kampala and Nairobi Cities. Open Access Library Journal, 8: e7389.

https://doi.org/10.4236/oalib.1107389

Received: April 5, 2021

Accepted: June 26, 2021

Published: June 29, 2021

Copyright $\odot 2021$ by author(s) and Open Access Library Inc.

This work is licensed under the Creative Commons Attribution International License (CC BY 4.0).

http://creativecommons.org/licenses/by/4.0/

(c) (i) Open Access

\begin{abstract}
A novel highly infectious disease (Corona virus disease-2019, COVID-19) has been an unprecedented global crisis. Following COVID-19 break out from Wuhan to the rest of the world, various countries adopted partial or total lockdowns to curb its progression or mitigate it. Lockdowns left drastic effects on health, physiological, social, economic and environmental fronts. This study reports on the impacts of COVID-19-induced human mobility restrictions on atmospheric levels of nitrogen dioxide $\left(\mathrm{NO}_{2}\right)$ and particulate matter represented in absorbing aerosol index (AAI) in Kampala, Nairobi and Dar es Salaam cities of Uganda, Kenya and Tanzania in the East African Community. Using satellite data, it was found that $\mathrm{NO}_{2}$ emissions decreased by about $6.0 \%$ and $8.91 \%$ in Kampala and Nairobi whereas AAI decreased by about $1.91 \%$ in 2020 . In Dar es Salaam, $\mathrm{NO}_{2}$ emissions increased by about $1.16 \%$ while the AAI remained almost constant in the same period. It is concluded that although there were substantial reductions in air pollution during 2020 (particularly the COVID-19 lockdown periods) in Kampala and Nairobi, these are not sustainable and deterioration of air quality after lifting of the restrictions has started to occur. Therefore, legislative actions need to be upheld to maintain air quality within the recommended levels.
\end{abstract}

\section{Subject Areas}

Environmental Chemistry, Air Pollution 


\section{Keywords}

Absorbing Aerosol Index, Nitrogen Dioxide, Particulate Matter, Corona Virus Disease-19 (COVID-19)

\section{Introduction}

The Coronavirus disease-2019 (COVID-19) pandemonium has been a tragedy with outlasting aggregate health, environmental and economic impacts globally [1]. COVID-19, whose causative virus is a positive-sense single-stranded RNA $\beta$-coronavirus (SARS-CoV-2) is highly infective [2] as evidenced by its rapid spill over to the rest of the world from China between December 2019 and March 2020 [3]. It was first appreciated among a cluster of 27 pneumonia-like case patients in the Chinese city of Wuhan (Hubei province) on $12^{\text {th }}$ December 2019 before it gripped onto the rest of the world. The virus marks the seventh incidence of coronaviruses ever reported in human history. COVID-19 was declared a Public Health Emergency of International Concern on January $30^{\text {th }}$, 2020 by the World Health Organization [4] before it was finally announced as a pandemic on March 22 $2^{\text {nd }}, 2020$ [5]. To curb the spillage of the ill-fated virus, most countries initially imposed lockdowns and restricted international flights, which paralyzed most industrial activities. As of $1^{\text {st }}$ February 2021, at least 2,222,647 mortalities and 102,584,351 confirmed cases of COVID-19 had been reported globally, with the United States of America in the lead of the highest number of reported cumulative cases [6].

The East African Community (EAC), just like the rest of the world suffered the brunt of COVID-19 which reached it by importation. Kenya was the first to record its coronavirus case on $12^{\text {th }}$ March 2020, followed by Rwanda and Tanzania on $14^{\text {th }}$ and $16^{\text {th }}$ March 2020, Uganda on March $21^{\text {st }}, 2020$ while Burundi and South Sudan registered their first cases on $25^{\text {th }}$ March 2020 and $5^{\text {th }}$ April 2020 [7]. Of these countries, Rwanda and Uganda initially contained the pandemic quite well, compared to others. As of $1^{\text {st }}$ February 2021 (the time of this writing), at least 161,726 confirmed cases, 112,742 recoveries and 2370 mortalities due to COVID-19 have been reported in the EAC [8].

The EAC embraced COVID-19 containment measures including mandatory institutional and self-quarantines, social distancing, restriction of international flights to and from high-risk countries, reduction of economic and social activities i.e. lockdowns and curfews. Rwanda was the first country in the EAC and Sub-Saharan Africa at large to implement total lockdown on $17^{\text {th }}$ March 2020. This was later followed by Uganda on $31^{\text {st }}$ March 2020 as a presidential strategy to curb the pandemic spread. Kenya imposed initially a partial lockdown on $6^{\text {th }}$ April 2020 but later extended it to a total lockdown as COVID-19 cases increased [7]. This study reported on the impacts of the pandemic-induced human mobility restrictions on atmospheric levels of nitrogen dioxide emissions and 
particulate matter represented in absorbing aerosol index in Kampala, Nairobi and Dar es Salaam cities of the EAC.

\section{Methods}

\subsection{Study Area and Selection of Studied Cities}

The current study was undertaken in the EAC, a consortium of countries forming one of the developing communities of the world. It is a regional intergovernmental organization of six (6) partner states (Figure 1) in the African Great Lakes region of Eastern Africa namely: Uganda, Kenya, Rwanda, Tanzania, Burundi and South Sudan. Its headquarters is in Arusha, Tanzania [9].

As outliers with Burundi among the East African responses to COVID-19 pandemic, Tanzania (Dar es Salaam) was considered in this study as a reference rather than a case study. The two countries (Uganda and Kenya) have been chosen because the former enforced a complete lockdown earlier while the latter started with a partial lockdown followed by a total lockdown. The major determining factors for the choice of these countries were because they were the only countries in the EAC for which nitrogen dioxide $\left(\mathrm{NO}_{2}\right)$ emissions satellite data were available from National Aeronautics and Space Administration (NASA) database.

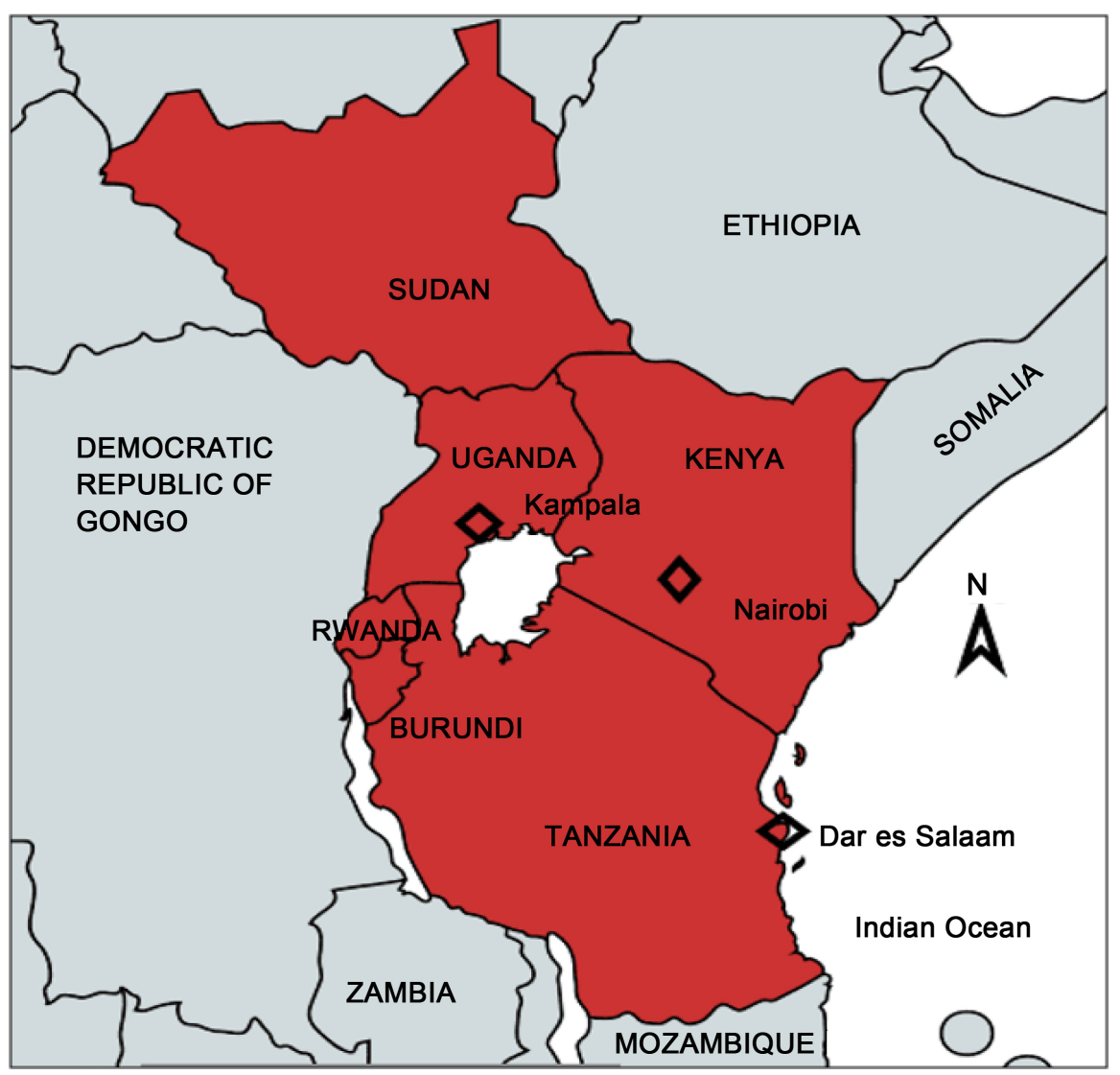

Figure 1. Map of East African Community showing member countries with the cities under study. 


\subsection{Study Design}

This study used satellite monitoring measurements for air pollutants recorded from the onset of COVID-19 in January 2020 through partial to complete COVID-19 lockdowns until December 2020 in the EAC. The baseline period used were the years 2015-2019 for nitrogen dioxide emissions and 2019 for the absorption aerosol index. We adopted this approach because the faculty of satellite devices in remote sensing of the lower troposphere has improved considerably over the years. Aerosol factors, for instance, are verifiable on spatial scales of a few kilometers using the space-borne radiometers [10]. Further, nitrogen dioxide along with other trace gases can be effectively identified on urban levels using spectrometers [10]. Unlike field monitoring stations that forecasts only vacillations in air quality or assess emissions at discrete points, satellite monitoring offsets this drawback with its faculty to model horizontal transportation of air pollutants for both long- and short periods [11]. This singular aspect, enhances greatly, synoptic and geospatial knowledge of ground-based air quality data [11]. In this context, data from satellite monitoring can be harnessed for establishing regions with the highest concentrations or furnishing warnings of upcoming air quality events such as wildfires and dust storms. Another advantage conferred by satellite systems is supplying air quality information for regions devoid of surface-based monitors [11].

\subsection{Nitrogen Dioxide Measurement}

In this study, changes in $\mathrm{NO}_{2}$ emissions before and during the COVID-19 pandemic year of 2020 were monitored by following Aura satellite data [12]. NASA launched Aura satellite on July $15^{\text {th }}$ 2004. It is equipped with an ozone monitoring instrument (OMI) to monitor the changes in air quality for various regions worldwide [13]. The OMI satellite instruments precisely detect air pollutants such as $\mathrm{NO}_{2}$, ozone, sulfur dioxide, carbon monoxide and methane [14]. The tools compute backscattered radiations from the sun in a broad spectral range from ultraviolet (UV) to infrared wavelengths. Advanced retrieval algorithms are thereafter applied to transform the measured radiation to pollutant concentrations, such as a tropospheric column density of $\mathrm{NO}_{2}$ [15].

\subsection{Absorbing Aerosol Index}

The absorbing aerosol index (AAI) data for 2019 and 2020 were obtained from Tropospheric Emission Monitoring Internet Service [16] of the European Space Agency (ESA).

\subsection{Data Analysis}

Data retrieved from satellite monitoring assessments during the COVID-19 pandemic lockdown were compared with both statutory and international air quality compliance standards. 


\section{Results and Discussion}

\subsection{Changes in Nitrogen Dioxide Emissions}

Data for $\mathrm{NO}_{2}$ emissions were retrieved from OMI for January 2020 to December 2020 and the baseline years (2015-2019). Data for the targeted months (March, April and May) in 2020 represents the peak of the pandemic with total or partial lockdowns in Uganda and Kenya, while Tanzania had no such containment measure in the same period. Comparison of the data for each month in 2020 with those of the previous five years (2015 to 2019) aimed at logically identifying whether the implemented containment measures during COVID-19 outbreak had an effect on $\mathrm{NO}_{2}$ emissions in Uganda and Kenya or not. In Figures 2-4, the darker the color, the higher $\mathrm{NO}_{2}$ concentration/emission is [15] [17].

Data retrieved indicated that $2020 \mathrm{NO}_{2}$ emissions in Kampala and Nairobi were lower than the average levels in the respective cities during the same months in 2015-2019. It is clearly observed that the orange colors in Figure 2 and Figure 3 are darker for 2020 than for 2015-2019, indicating there was a reduction in $\mathrm{NO}_{2}$ emissions in 2020 during the COVID-19 pandemic.

A percentage difference was calculated inside a $1^{\circ} \times 1^{\circ}$ box over Kampala (Figure 2). In January 2020, $\mathrm{NO}_{2}$ emissions in Kampala were $16 \%$ lower than the baseline. This could be due to the reduced movements during the festive season. In February 2020, $\mathrm{NO}_{2}$ emissions were only 9\% lower than the baseline in Kampala. This is because during February, most schools and tertiary institutions had reopened, which translates into increased vehicular movements. By March $18^{\text {th }}$ 2020 when total lockdown along with other containment strategies were adopted in Uganda to reduce the spread of COVID-19 [18] [19] [20], $\mathrm{NO}_{2}$ emissions over Kampala dropped by about $2 \%$ compared with the baseline period (Figure 2(c)). From April $1^{\text {st }} 2020$ to May $1^{\text {st }} 2020, \mathrm{NO}_{2}$ emission over Kampala reduced by $12 \%$ and 3\%, respectively. The lower percentage reduction in May 2020 could be because the government eased some restrictions despite maintaining lockdown in late April and early May [21] [22]. This also explains the lower percentage reductions in $\mathrm{NO}_{2}$ emissions $(10 \%, 3 \%, 17 \%, 0 \%, 6 \%$ and $8 \%)$ lower than the baseline recorded between June and November 2020, as the government allowed vehicular movements with restricted number of passengers (carrying half their capacity), reduced curfew hours and removed total lockdown, and allowed resumption of work and commercial activities to reduce risks of economic recession [23] [24]. In December 2020 (Figure 2(1)), $\mathrm{NO}_{2}$ emissions in Kampala was $8 \%$ greater than the baseline. This could be in addition to the foregoing reasons, increased movements in preparation for the festive season (Christmas celebration on $25^{\text {th }}$ December 2020 and New Year celebration on $1^{\text {st }}$ January 2021) as well as increased campaign activities in preparation for elections which occurred from $14^{\text {th }}$ January 2021 up to early February 2021.

For Nairobi (Kenya), a percentage difference was calculated inside a $1^{\circ} \times 1^{\circ}$ box over it. As depicted in Figure 3, $\mathrm{NO}_{2}$ emissions were $18 \%$ greater than the baseline in January 2020 but this increased to 20\% lower than the baseline in 

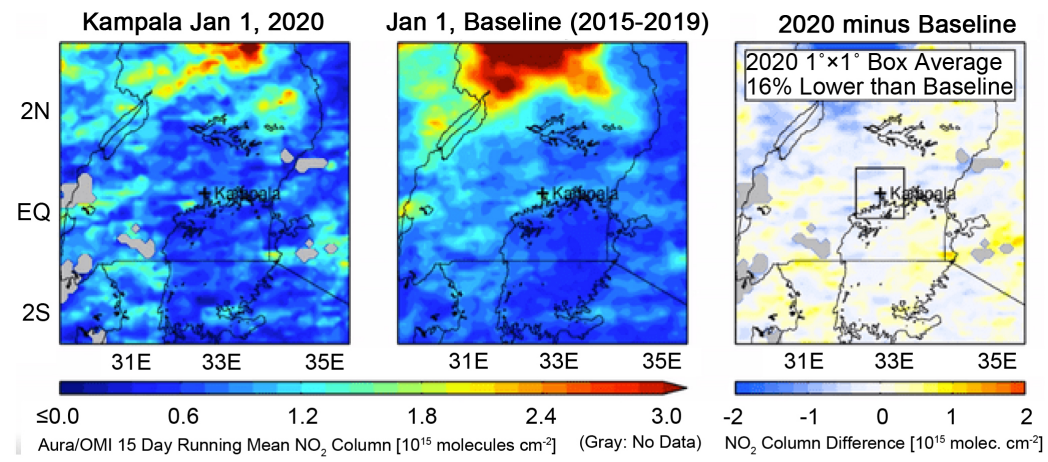

(a)

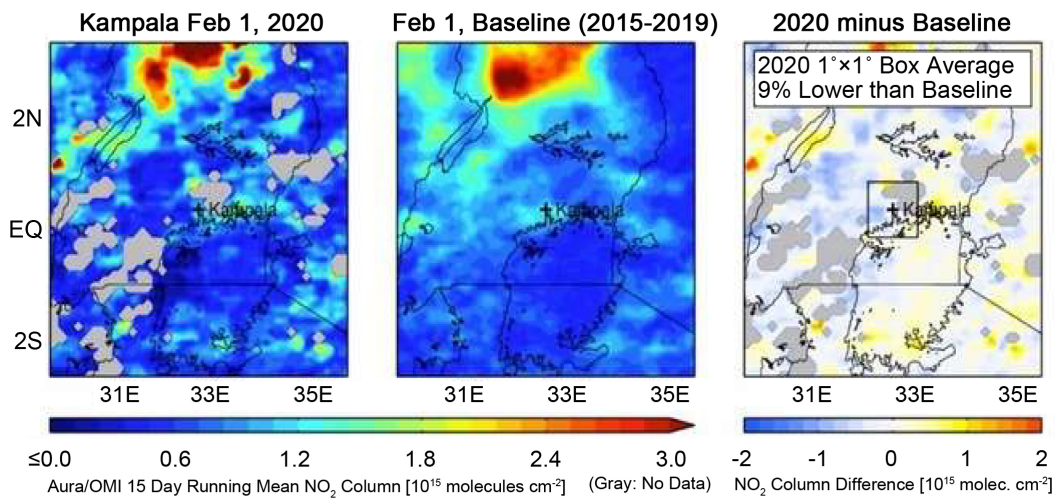

(b)

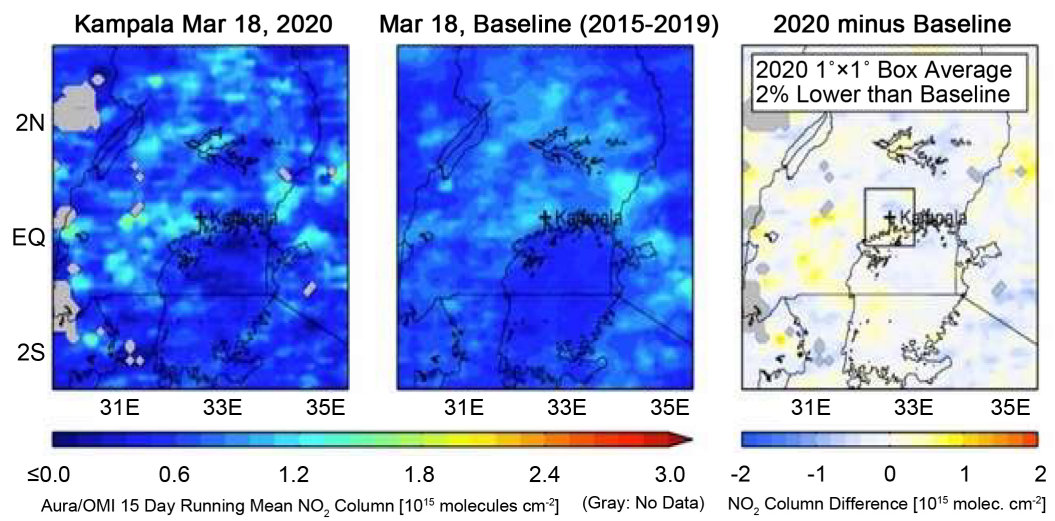

(c)

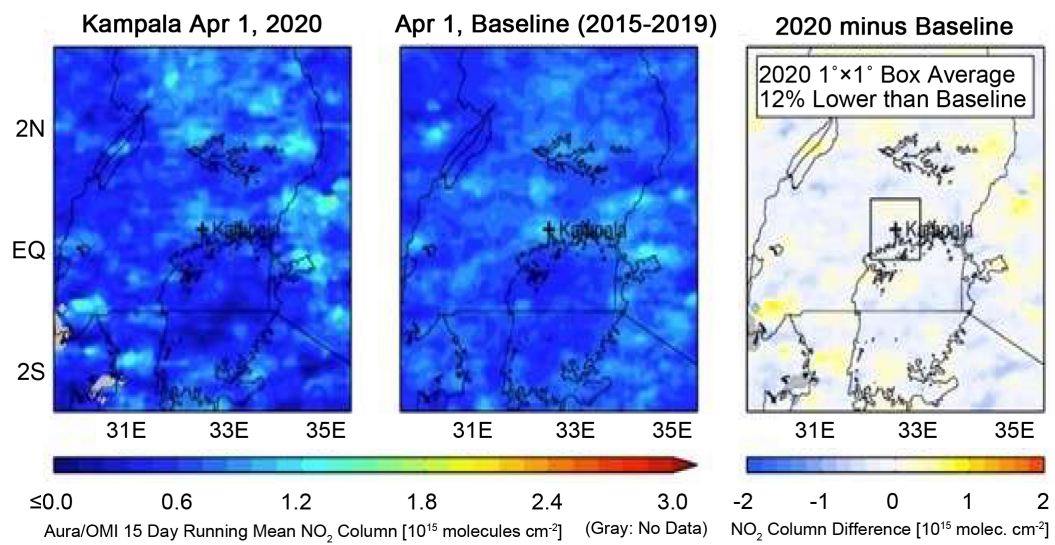

(d) 


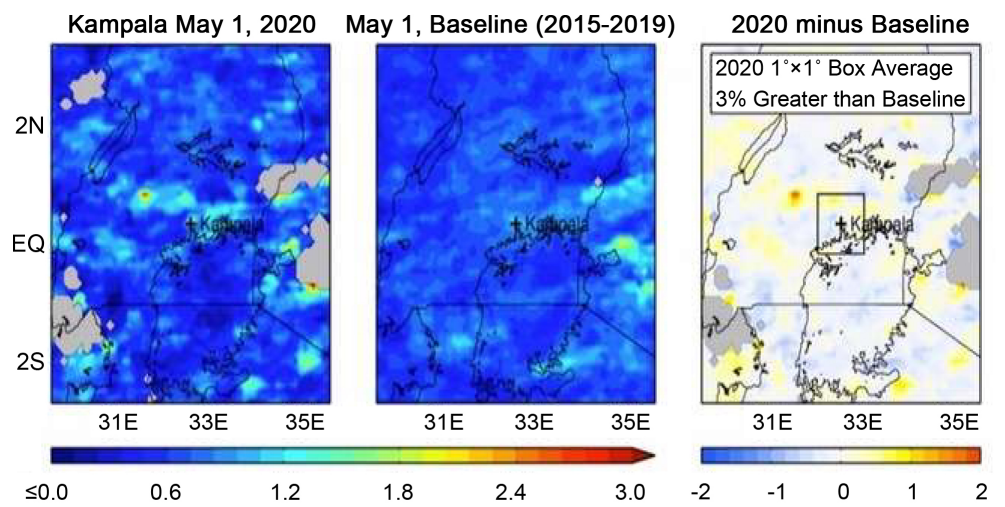

Aura/OMI 15 Day Running Mean $\mathrm{NO}_{2}$ Column [1015 molecules $\mathrm{cm}^{-2}$ (Gray: No Data) $\mathrm{NO}_{2}$ Column Difference $\left[10^{15}\right.$ molec. $\left.\mathrm{cm}^{-2}\right]$

(e)

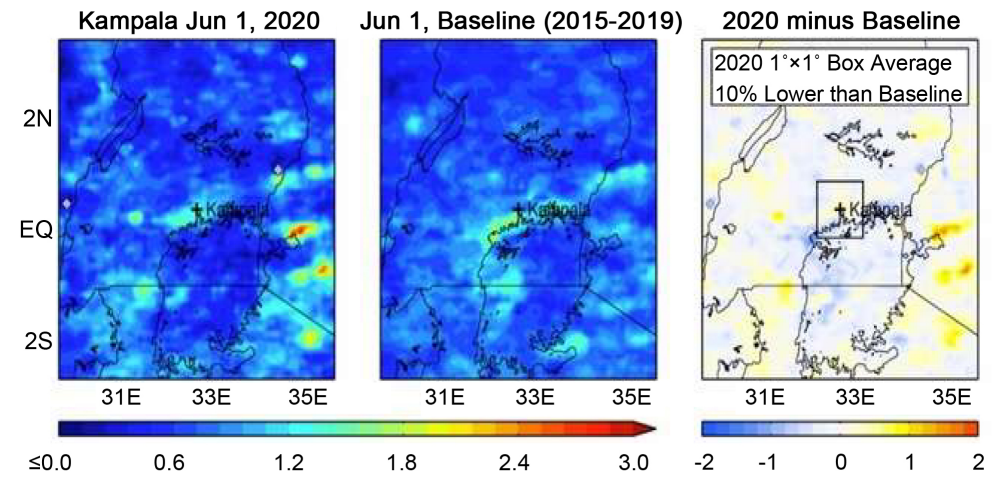

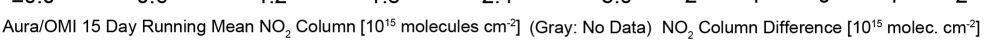

(f)

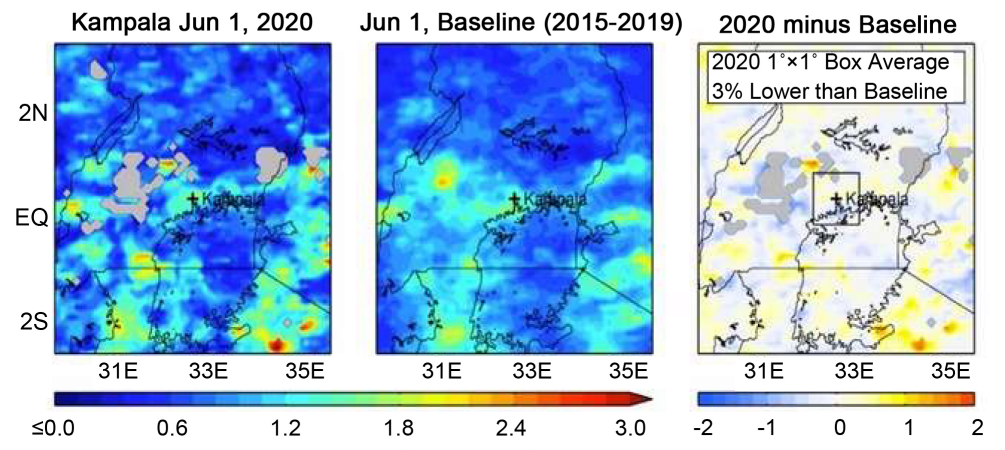

Aura/OMI 15 Day Running Mean $\mathrm{NO}_{2}$ Column $\left[10^{15}\right.$ molecules $\left.\mathrm{cm}^{-2}\right]$ (Gray: No Data) $\mathrm{NO}_{2}$ Column Difference $\left[10^{15} \mathrm{molec}^{\left.-\mathrm{cm}^{-2}\right]}\right.$

(g)

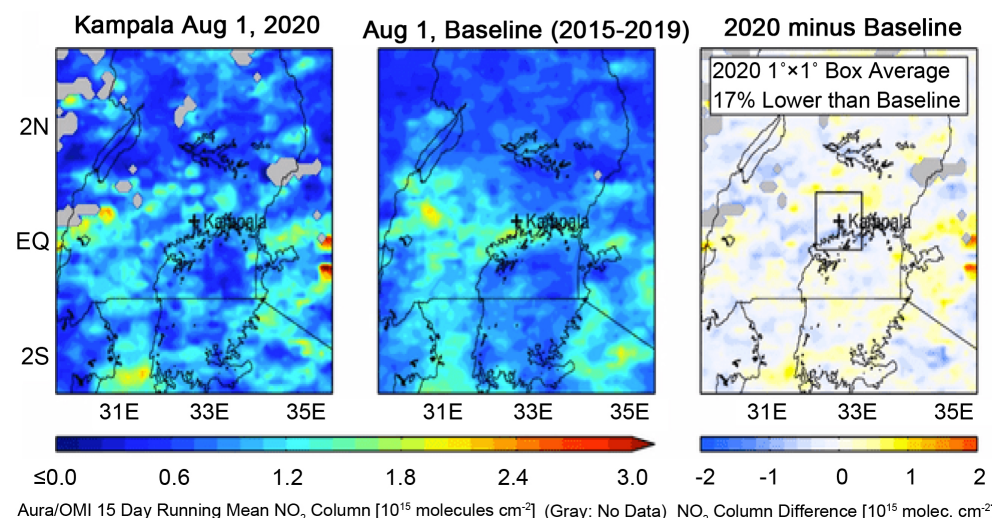

(h) 


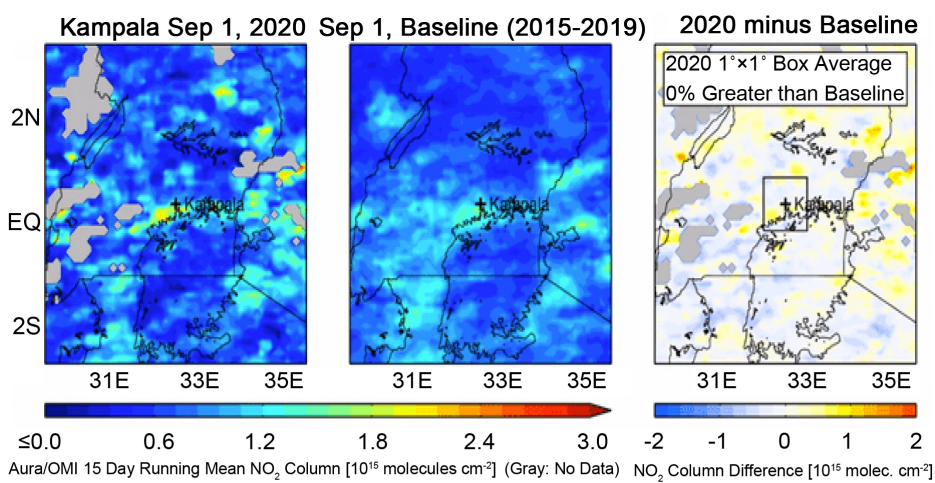

(i)

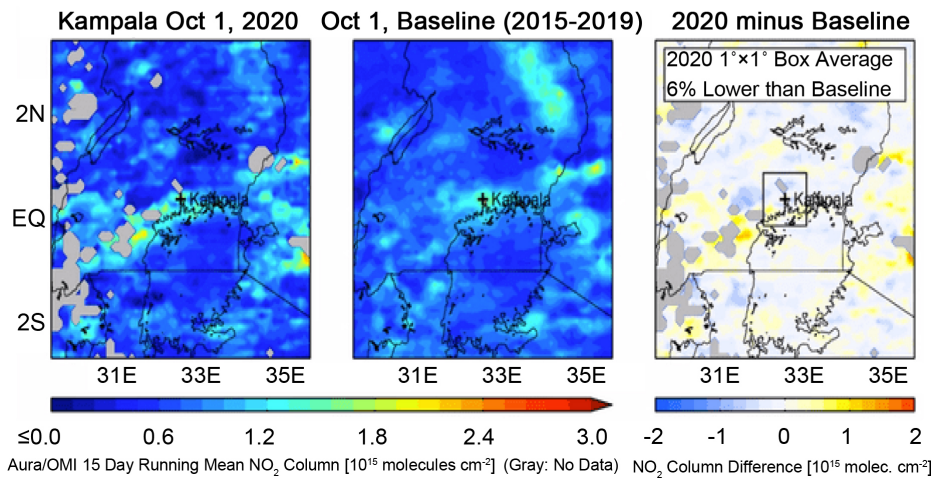

(j)

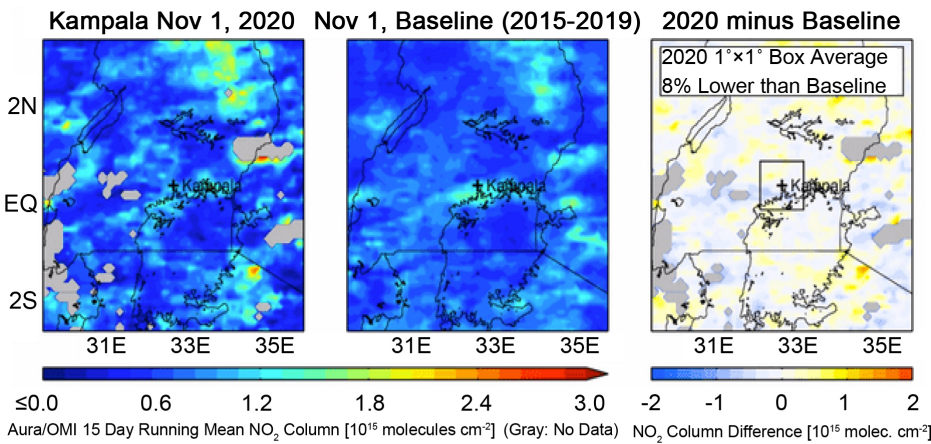

(k)

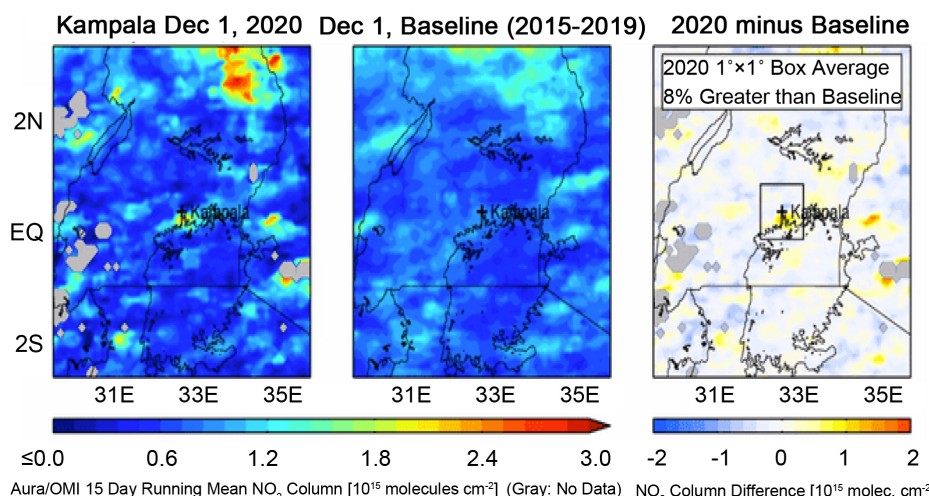

(l)

Figure 2. Tropospheric $\mathrm{NO}_{2}$ emissions over Kampala, Uganda (32.58E, 0.35N) for 2020 and the baseline (2015-2019). Results are for $1^{\circ}$ Latitude $\times 1^{\circ}$ Longitude box around city center. 


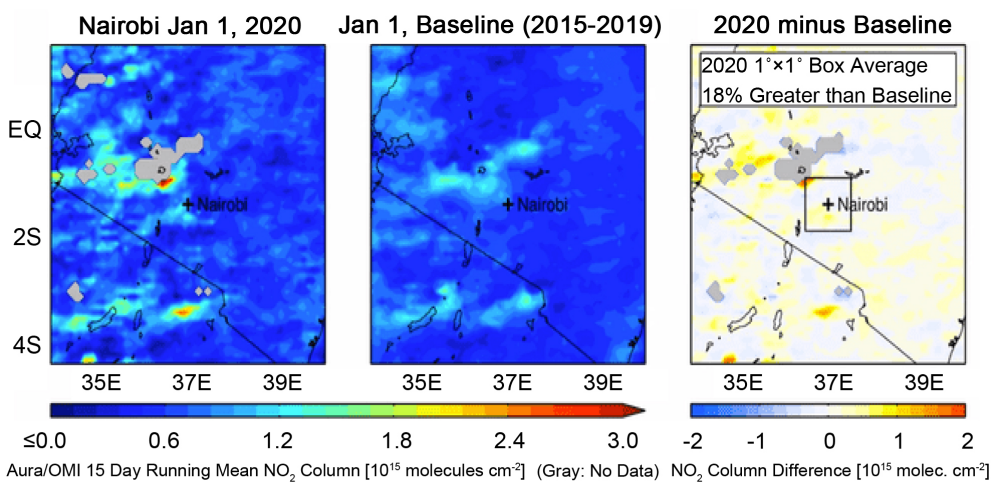

(a)

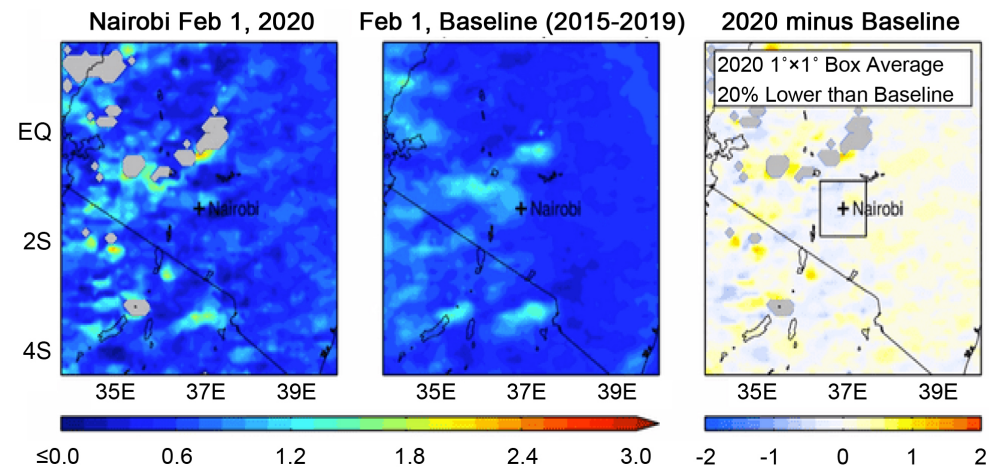

Aura/OMI 15 Day Running Mean $\mathrm{NO}_{2}$ Column [1015 molecules $\left.\mathrm{cm}^{-2}\right]$ (Gray: No Data) $\mathrm{NO}_{2}$ Column Difference $\left[10^{15}\right.$ molec. $\left.\mathrm{cm}^{2}\right]$

(b)

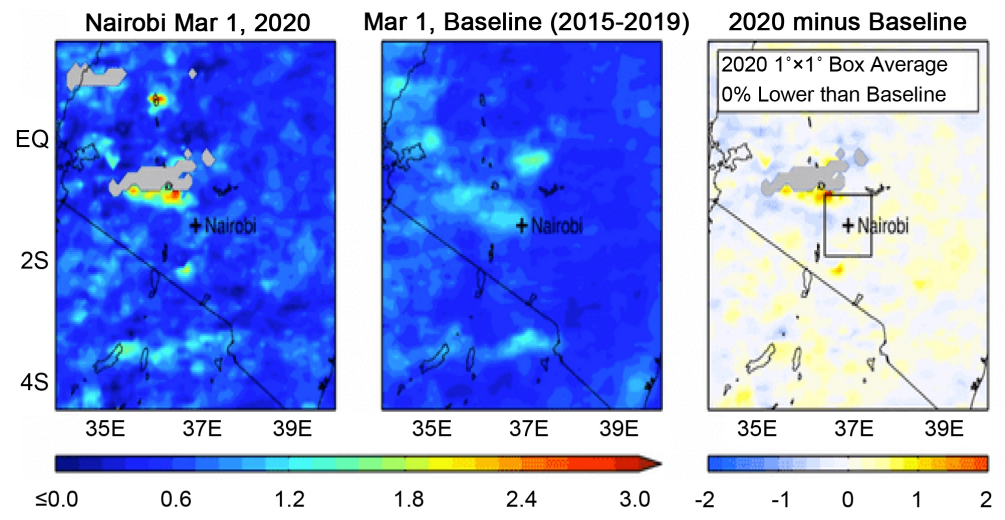

Aura/OMI 15 Day Running Mean $\mathrm{NO}_{2}$ Column [1015 molecules $\left.\mathrm{cm}^{-2}\right]$ (Gray: No Data) $\mathrm{NO}_{2}$ Column Difference $\left[10^{15} \mathrm{molec} . \mathrm{cm}^{-2}\right]$

(c)

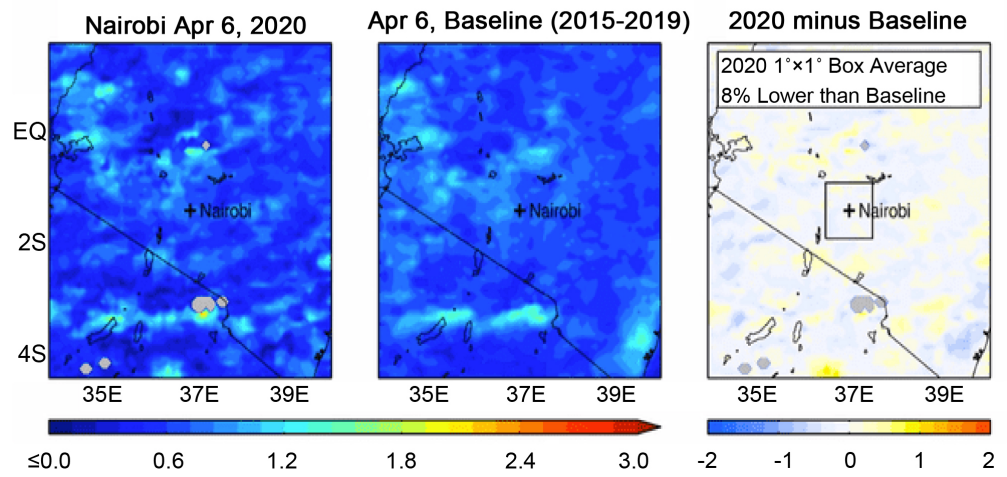

Aura/OMI 15 Day Running Mean $\mathrm{NO}_{2}$ Column [1015 molecules $\left.\mathrm{cm}^{-2}\right]$ (Gray: No Data) $\mathrm{NO}_{2}$ Column Difference [1015 molec. $\left.\mathrm{cm}^{-2}\right]$

(d) 


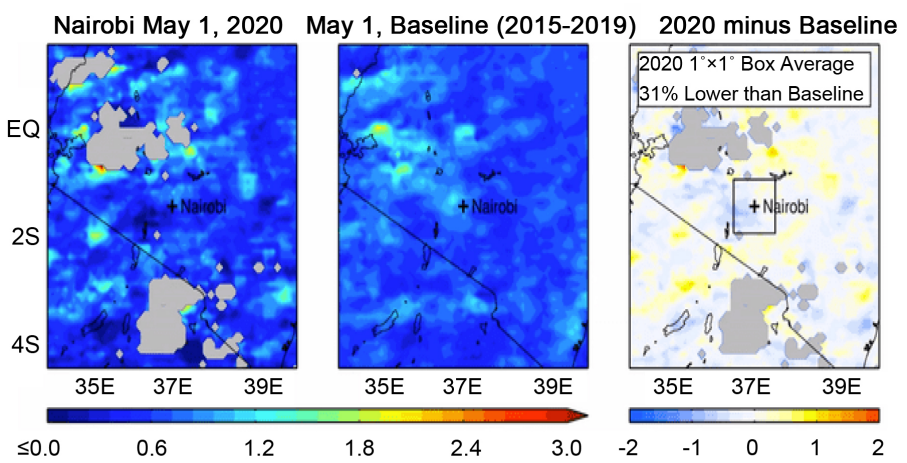

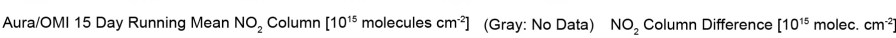

(e)

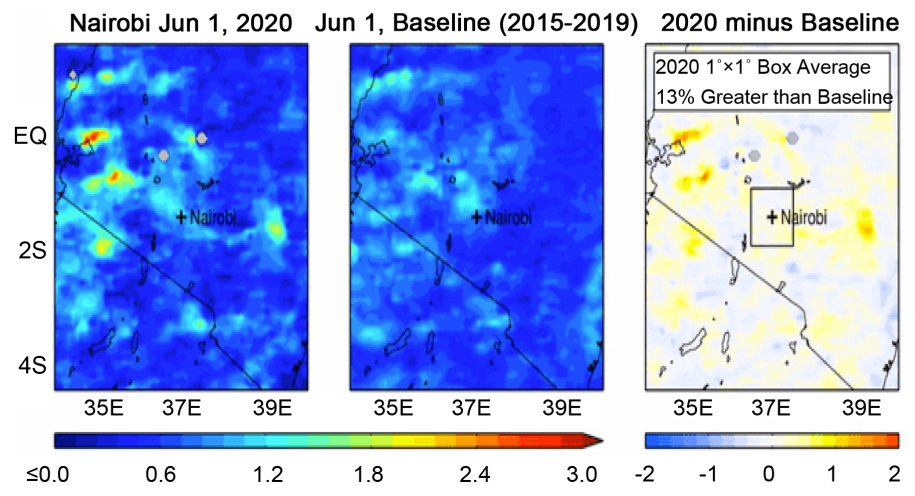

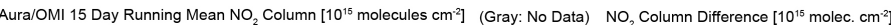

(f)

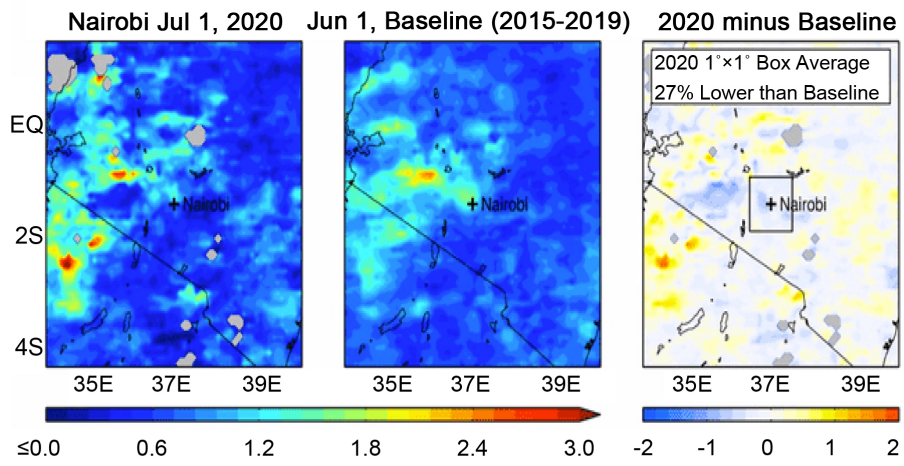

Aura/OMI 15 Day Running Mean $\mathrm{NO}_{2}$ Column [1015 molecules $\left.\mathrm{cm}^{-2}\right]$ (Gray: No Data) $\mathrm{NO}_{2}$ Column Difference $\left[10^{15} \mathrm{molec} . \mathrm{cm}^{-2}\right]$

(g)

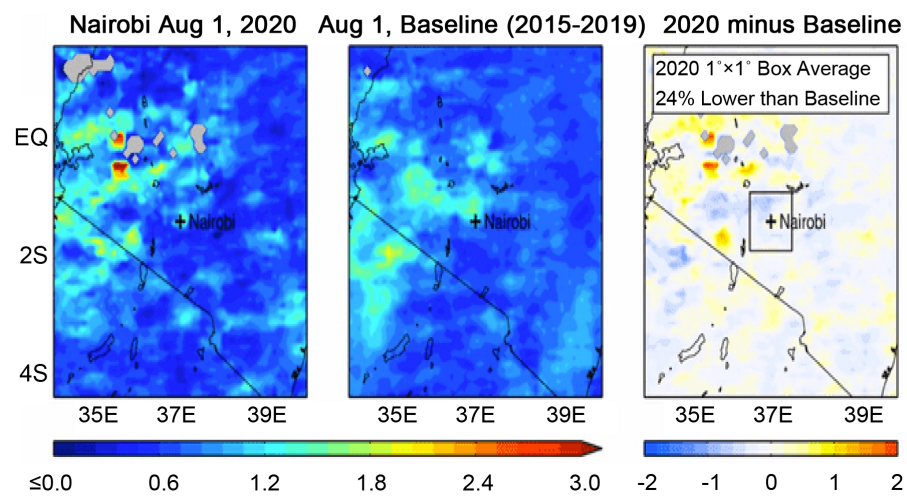

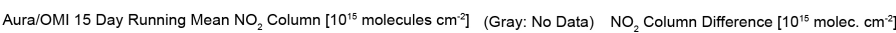

(h) 


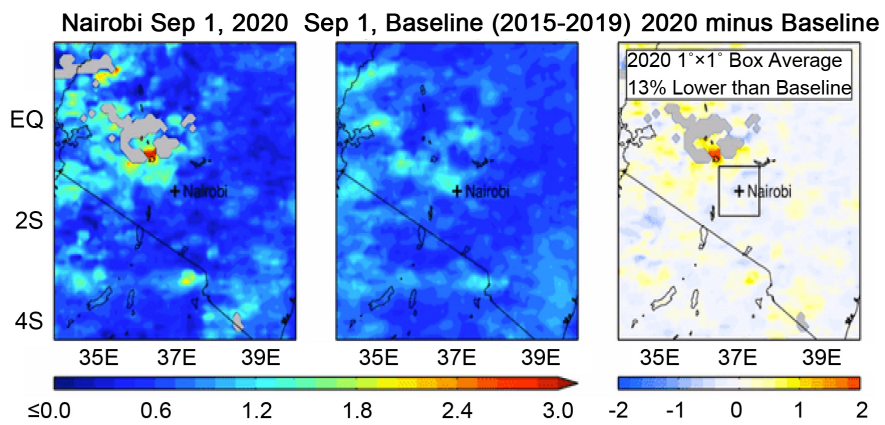

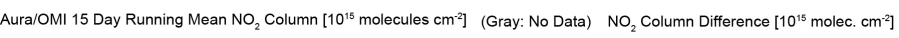

(i)

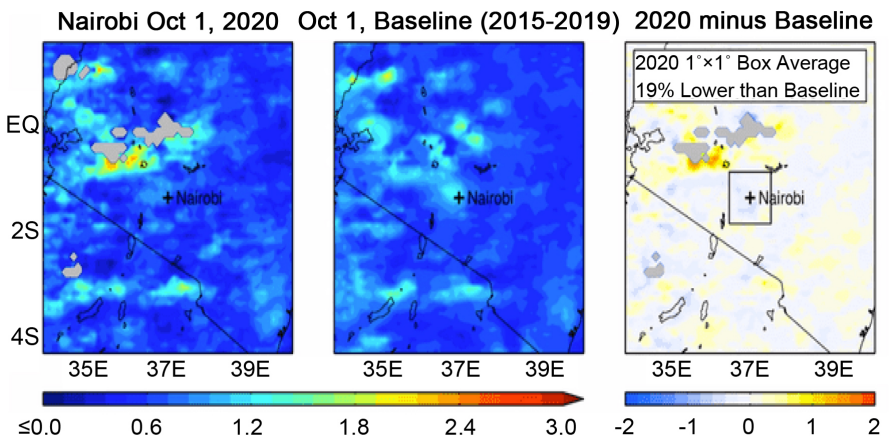

Aura/OMI 15 Day Running Mean $\mathrm{NO}_{2}$ Column [1015 molecules $\left.\mathrm{cm}^{-2}\right]$ (Gray: No Data) $\mathrm{NO}_{2}$ Column Difference $\left[10^{15} \mathrm{molec} . \mathrm{cm}^{-2}\right]$

(j)

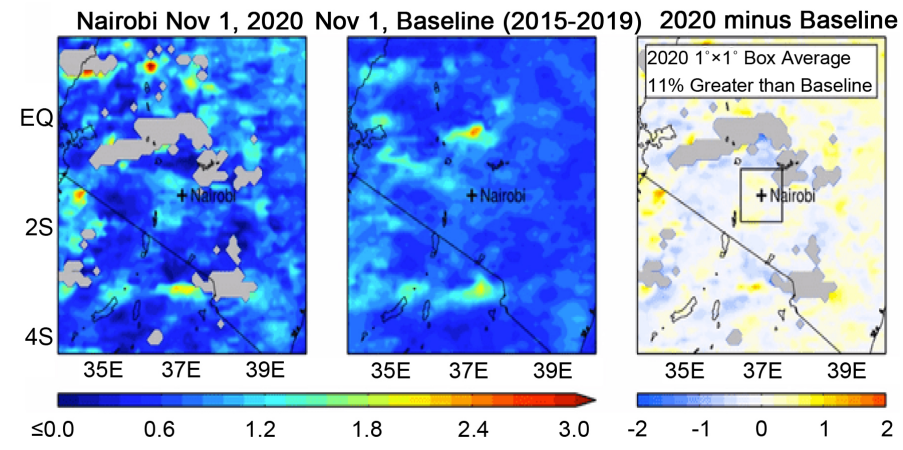

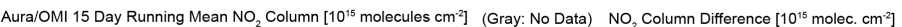

(k)

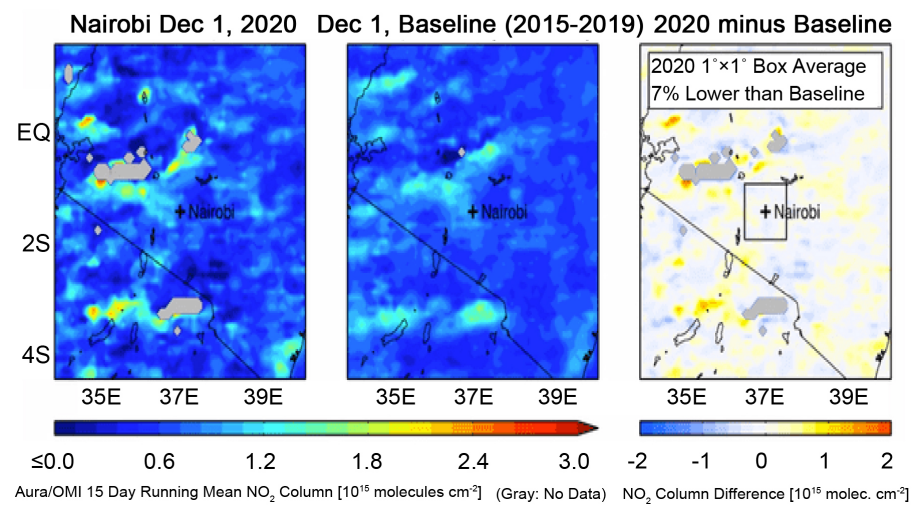

(1)

Figure 3. Tropospheric $\mathrm{NO}_{2}$ emissions over Nairobi, Kenya (36.29E, 1.42S) for 2020 and the baseline (2015-2019). Results are for $1^{\circ}$ Latitude $\times 1^{\circ}$ Longitude box around city center. 


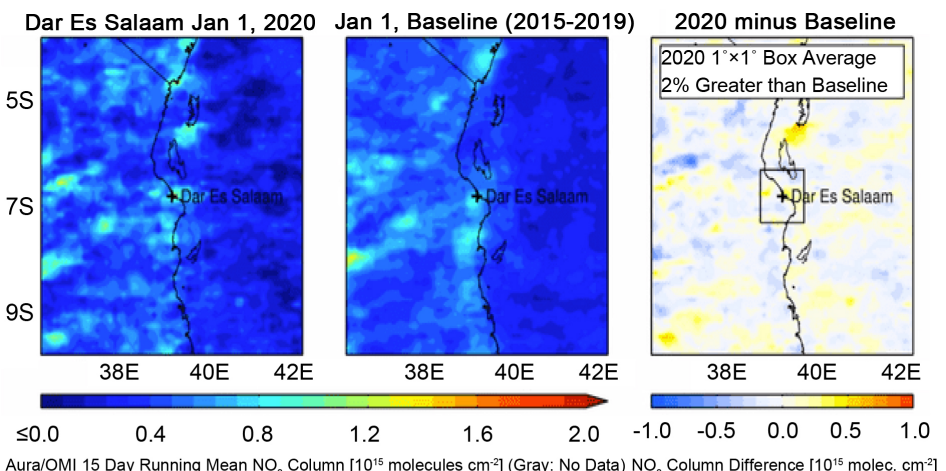

Aura/OMI 15 Day Running Mean $\mathrm{NO}_{2}$ Column $\left[10^{15}\right.$ molecules $\left.\mathrm{cm}^{-2}\right]$ (Gray: No Data) $\mathrm{NO}_{2}$ Column Difference $\left[10^{15} \mathrm{molec}^{\left.-\mathrm{cm}^{-2}\right]}\right.$

(a)

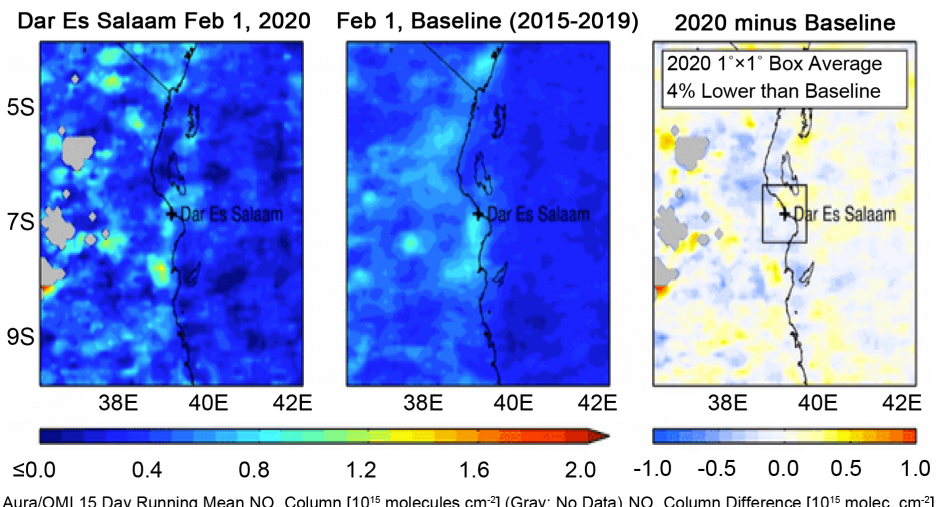

(b)

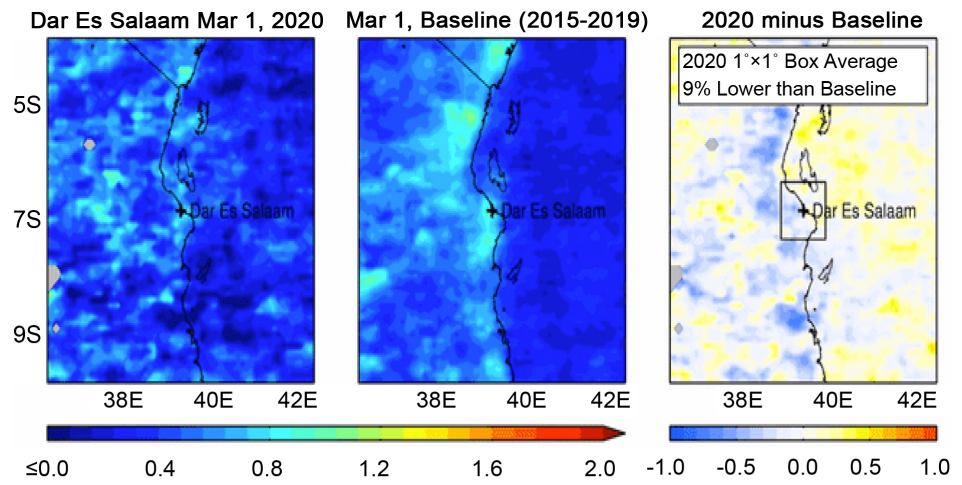

Aura/OMI 15 Day Running Mean $\mathrm{NO}_{2}$ Column [10 $10^{15}$ molecules $\mathrm{cm}^{-2}$ (Gray: No Data) $\mathrm{NO}_{2}$ Column Difference [1015 molec. $\left.\mathrm{cm}^{-2}\right]$

(c)

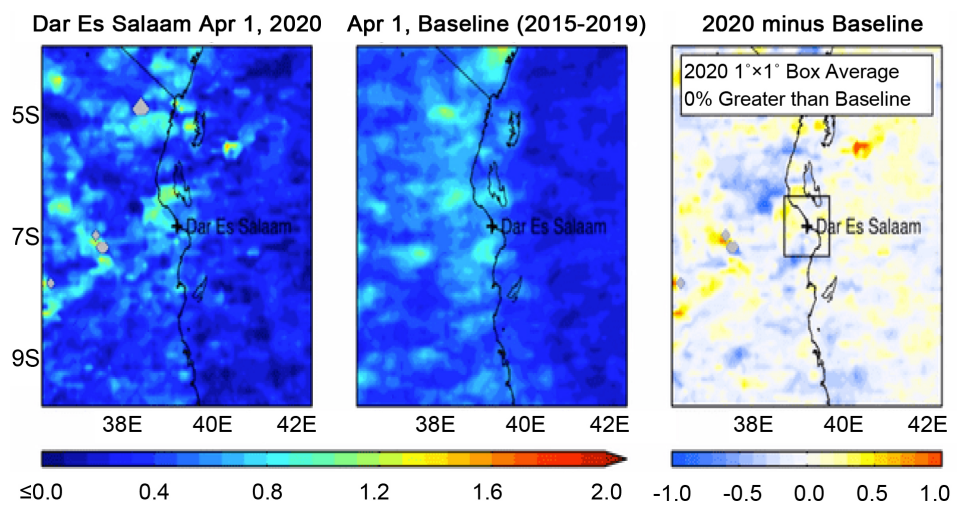

Aura/OMI 15 Day Running Mean $\mathrm{NO}_{2}$ Column [10 $10^{15}$ molecules $\left.\mathrm{cm}^{-2}\right]$ (Gray: No Data) $\mathrm{NO}_{2}$ Column Difference $\left[10^{15} \mathrm{molec}^{\left.-\mathrm{cm}^{-2}\right]}\right.$

(d) 


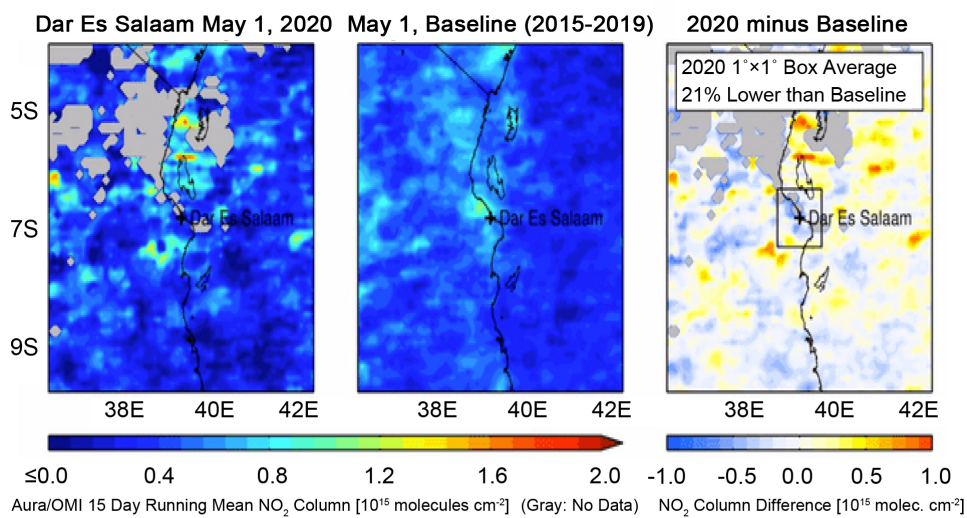

(e)

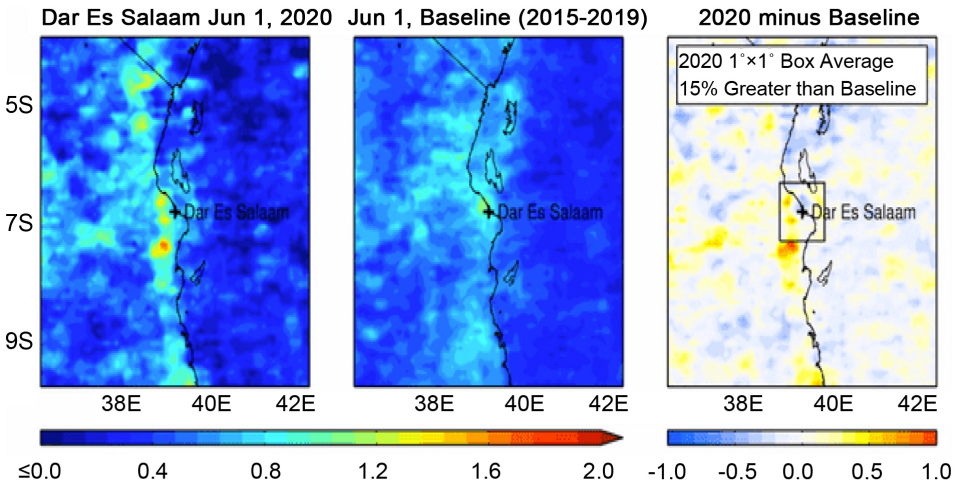

Aura/OMI 15 Day Running Mean $\mathrm{NO}_{2}$ Column [1015 molecules $\left.\mathrm{cm}^{-2}\right]$ (Gray: No Data) $\mathrm{NO}_{2}$ Column Difference $\left[10^{15} \mathrm{molec} . \mathrm{cm}^{-2}\right]$

$(f)$

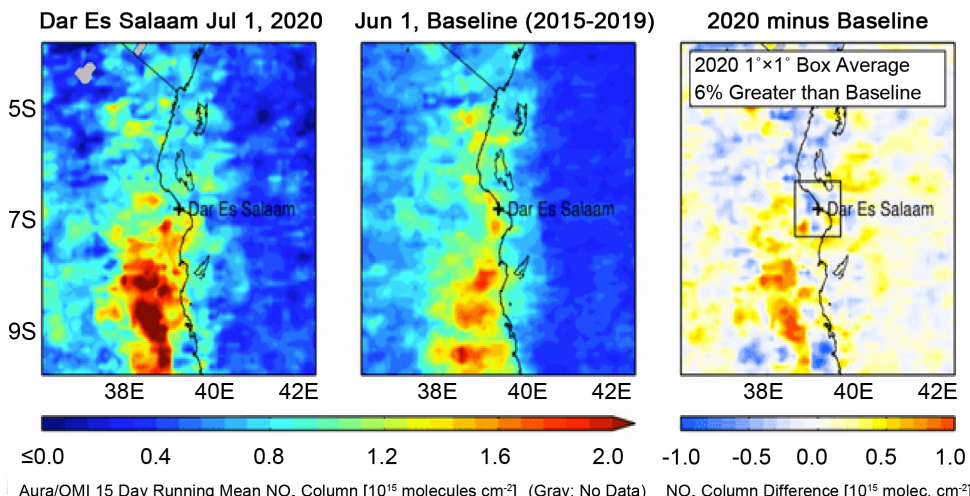

(g)

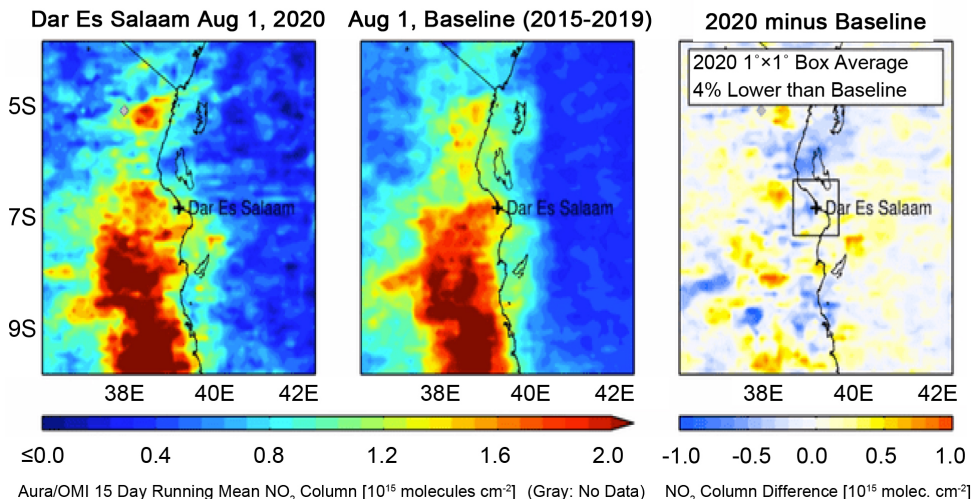

(h) 


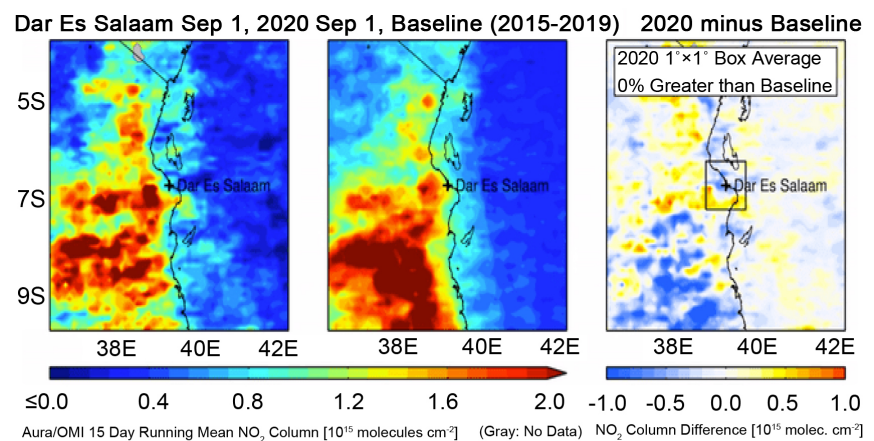

(i)

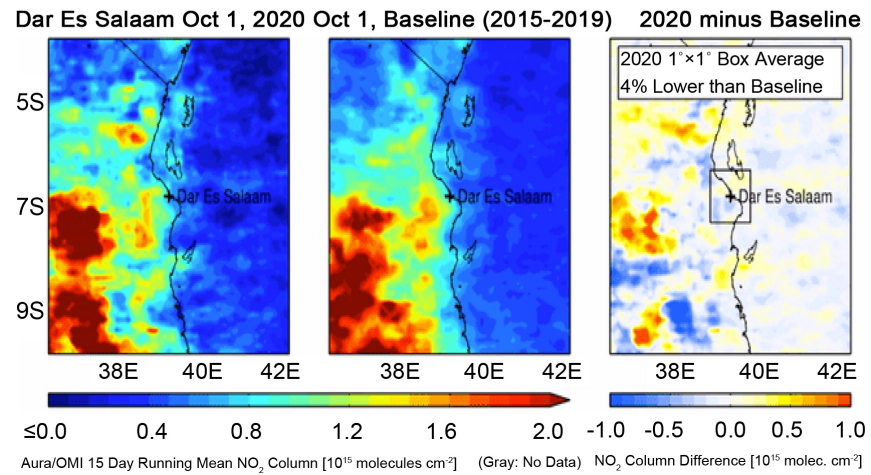

(j)

Dar Es Salaam Nov 1, 2020 Nov 1, Baseline (2015-2019) 2020 minus Baseline

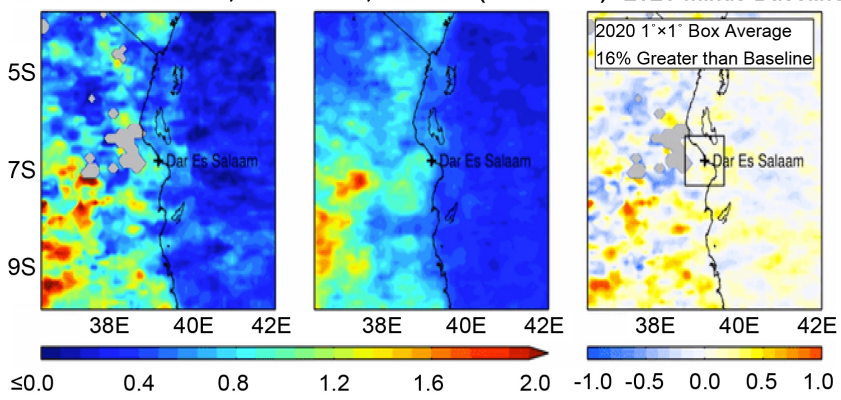

$(\mathrm{k})$

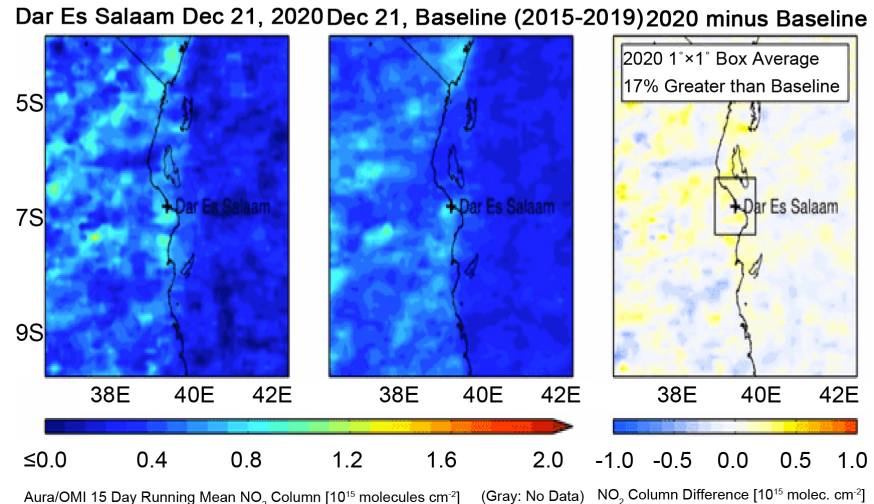

(l)

Figure 4. Tropospheric $\mathrm{NO}_{2}$ emissions over Dar es Salaam, Tanzania (39.25E, 6.80S) for 2020 and the baseline (2015-2019). Results are for $1^{\circ}$ Latitude $\times 1^{\circ}$ Longitude box around city center. 
February. This could be due to reduced industrial production post-festive season of 2019. On March $1^{\text {st }} 2020$, there was no net increase in $\mathrm{NO}_{2}$ emissions when compared to 2015-2019 baseline. On $6^{\text {th }}$ April 2020 when a partial lockdown was considered, $\mathrm{NO}_{2}$ emissions were $8 \%$ lower than the baseline. This could have been due to decreased industrial production and vehicular movements. For May, July, August, September, October, November and December, $\mathrm{NO}_{2}$ emissions in Nairobi were $31 \%, 27 \%, 24 \%, 13 \%, 19 \%, 11 \%$ and $7 \%$ lower than the baseline. On $1^{\text {st }}$ June $2020, \mathrm{NO}_{2}$ emissions were $13 \%$ greater than the baseline. The lower reductions in percentage emissions of $\mathrm{NO}_{2}$ from May to December 2020 could be due to the gradual easing of COVID-19 restrictions by the government, including allowing resumption of work, industrial activities and public transport i.e. vehicular movements [25]. Within Nairobi metropolitan area for example, movement restrictions in the Eastleigh area were lifted [26]. The November-December lower percentage reductions in $\mathrm{NO}_{2}$ emissions could also be explained by increased industrial production and vehicular movements ahead of the festive season (Christmas celebrations on $25^{\text {th }}$ December 2020 and the new year celebration of $1^{\text {st }}$ January 2021).

Interestingly, the observed reductions in $\mathrm{NO}_{2}$ emissions in 2020 over Kampala and Nairobi cities have not been the case with Tanzania where there was no lockdown instituted. As seen in Figure 4(a), Dar es Salaam had $4 \%$ greater $\mathrm{NO}_{2}$ emissions than the baseline on January $1^{\text {st }} 2020$ which reduced to $4 \%$ lower than the baseline in February 2020 (Figure 4(b)). In March when COVID-19 became a reality in the EAC, $\mathrm{NO}_{2}$ emissions dropped by $9 \%$ lower than the baseline (Figure $4(\mathrm{c})$ ). This could be because the country initially tried to follow WHO guidelines in containing the virus and reduced vehicular traffic in its coastal city of Dar es Salaam [27] [28]. In April 2020, there was no net difference between the $\mathrm{NO}_{2}$ emissions in the city as compared to the 2015-2019 baseline, but this increased to 21\% lower than the baseline in May 2020. When the president declared the country "coronavirus-free" in June 2020 and allowed free movements and operation of industries [29] [30], $\mathrm{NO}_{2}$ emissions increased by $15 \%$ and $4 \%$ greater than the baseline for June and July 2020 (Figure 4(f) and Figure 4(g)). After this, $\mathrm{NO}_{2}$ emissions were $4 \%$ lower than baseline in August 2020. There was no net difference in $\mathrm{NO}_{2}$ emissions over Dar es Salaam in September 2020 but this decreased to $4 \%$ lower than the baseline in October 2020. November 2020 and December 2020 recorded $16 \%$ and 17\% increase in $\mathrm{NO}_{2}$ emissions when compared to the baseline. This indicates that the lockdown containment measure could have had a reductive effect on $\mathrm{NO}_{2}$ emissions in Dar es Salaam.

Overall, there were about $6.0 \%$ and $8.91 \%$ reductions in $\mathrm{NO}_{2}$ emissions over Kampala and Nairobi in 2020 while Dar es Salaam had about $1.16 \%$ increase in $\mathrm{NO}_{2}$ emissions. These findings are in agreement with the percentage reduction in the use of gasoline and diesel from March 2020 for Kampala and Nairobi. Thus, the reductions in $\mathrm{NO}_{2}$ emissions could mainly be attributable to the reductions in vehicular traffic and industrial activities during the pandemic year 
(2020). The $\mathrm{NO}_{2}$ emissions reported were comparable to those retrieved from the Google community mobility reports based on anonymized datasets from users in Kampala and Nairobi cities [31] [32]. High air pollution levels in Tanzanian city of Dar es Salaam is not a new report; it had been reported by previous authors to be caused by its heavy traffic, especially in the rush hours [33] [34] [35].

Reduction in $\mathrm{NO}_{2}$ levels during the novel COVID-19 pandemic have been previously reported in other countries (cities) including China [17], Cairo and Alexandria governorates of Egypt [15], United States of America [1], India [36] [37], Kingdom of Saudi Arabia [38], Sao Paulo and Rio de Janeiro of Brazil [39] [40], Croatia [41], Barcelona of Spain [42], Southern European cities of Nice, Rome, Valencia and Turin [43] and Italian cities of Florence, Milan, Pisa and Lucca [44] [45].

The concentration of $\mathrm{NO}_{2}$ in the atmosphere is primarily a function of the magnitude of nitrogen oxide $\left(\mathrm{NO}_{\mathrm{x}}\right)$ emissions and weather factors such as sun angle, wind speed and temperature, though meteorological variations between years can cause column $\mathrm{NO}_{2}$ differences of $\sim 15 \%$ over monthly timescales [46]. It is clear that the implemented COVID-19 lockdowns (March to May) reduced $\mathrm{NO}_{2}$ emissions over Kampala and Nairobi, and thus improved air quality [47]. However, these improvements are temporary and unsustainable, with deterioration of air quality anticipated to upsurge as the countries resuscitate their economies post-lockdown or in the post-pandemic period as earlier witnessed in China [48]. It is imperative that stricter laws are enacted in the crucible of the fight against the virus itself so as to protect the environment of the individual countries, and the EAC at large.

\subsection{Changes in Absorbing Aerosol Index}

As depicted in Figure 5, the 2020 absorbing aerosol index (AAI) in Kampala and Nairobi were lower than the AAI level during the same period in 2019 for February 2020 to May 2020 by about $1.91 \%$, which confirms the positive effect of COVID-19 on air quality in Uganda and Kenya. In the other months, there were insignificant changes in AAI in Kampala and Nairobi. For Dar es Salaam, there were no appreciable increases in the AAI during the pandemic year. Recent reports indicate that much of the particulate matter emissions are from the transport sector (old private cars and taxis) from 6:00 am to 9:00 am in Kampala and the rest of Uganda [49], Nairobi [50] and Dar es Salaam [51]. This explains why lockdowns led to reduced AAI in the former than the latter. This is analogous to the situation reported previously in Egypt [52] [53].

The stringent containment measures adopted by Uganda and Kenyan governments led to less traffic flow and relatively fewer construction activities. Less traffic flow usually leads to less particulate matter (PM) emissions from automobile engines particularly from old taxis and public transportation buses, tyre and brake wears and unmaintained roads [15] [50] [54]. Previous authors reported similar attenuation in PM levels during the COVID-19 in countries (cities) of 


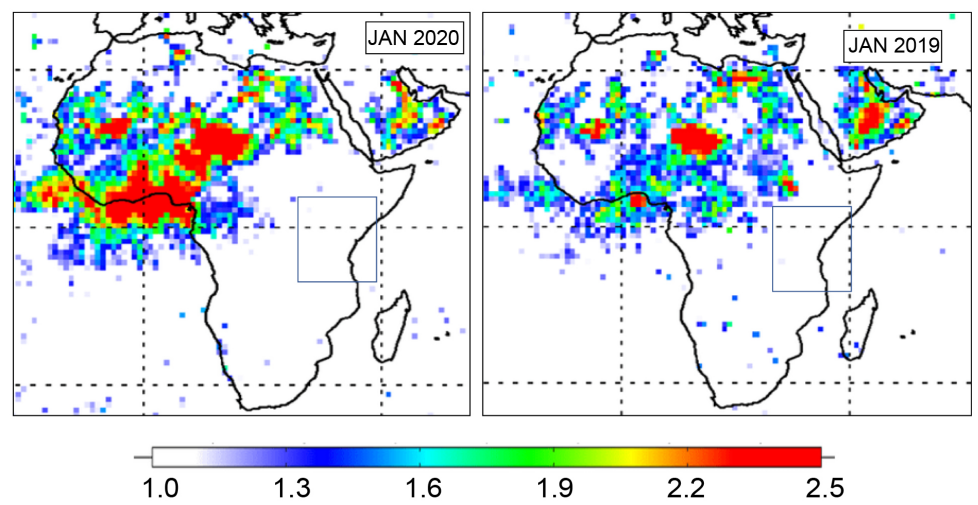

(a)

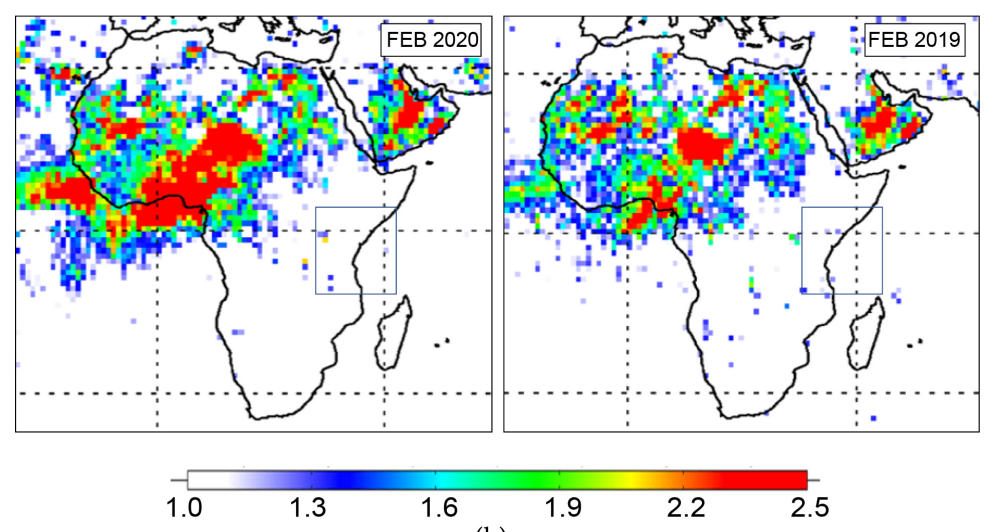

(b)

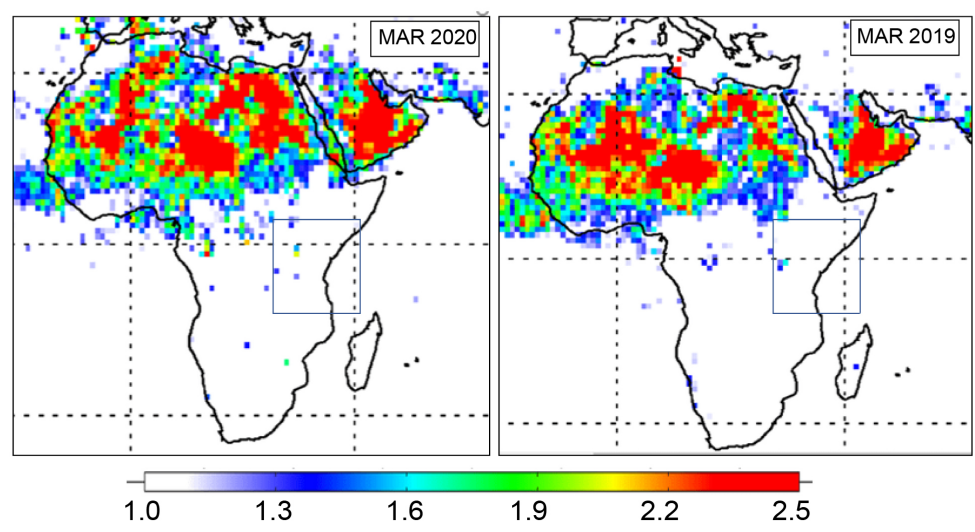

(c)

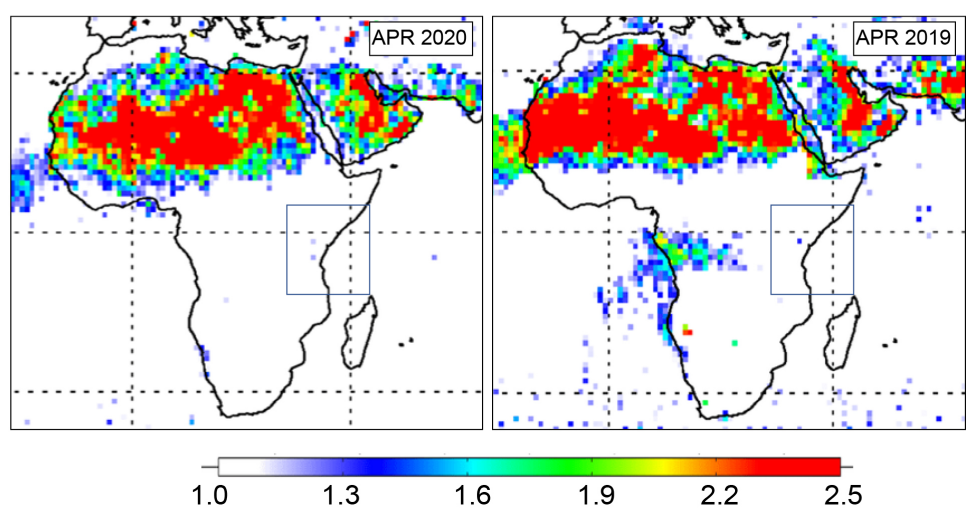

(d) 

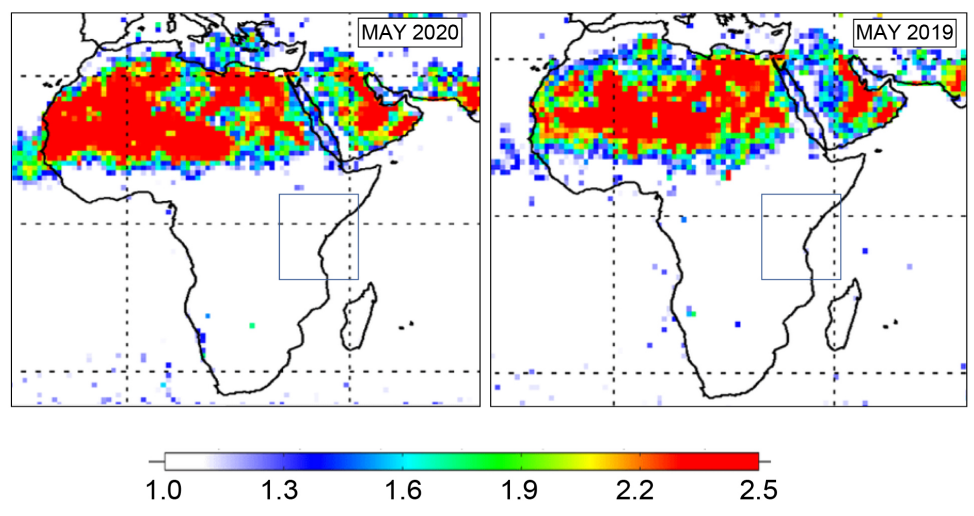

(e)
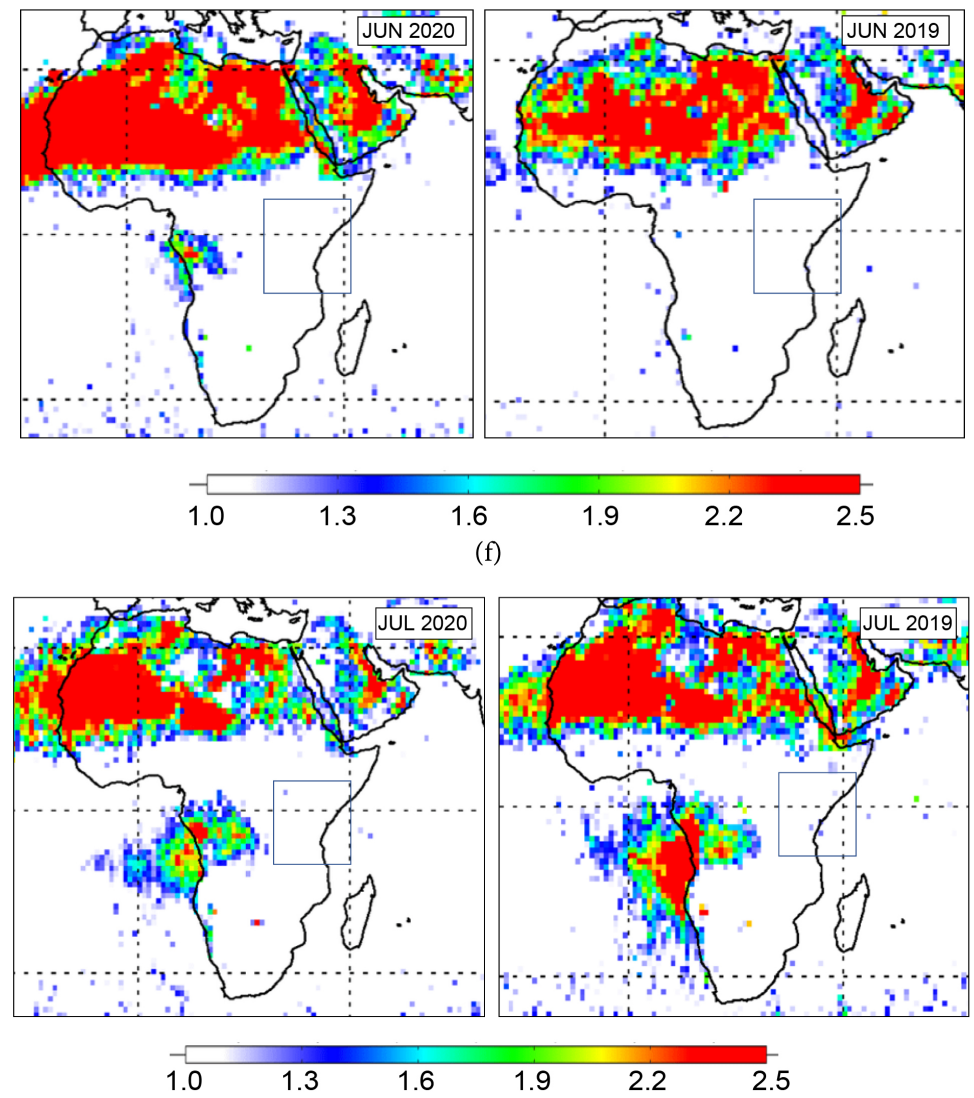

(g)

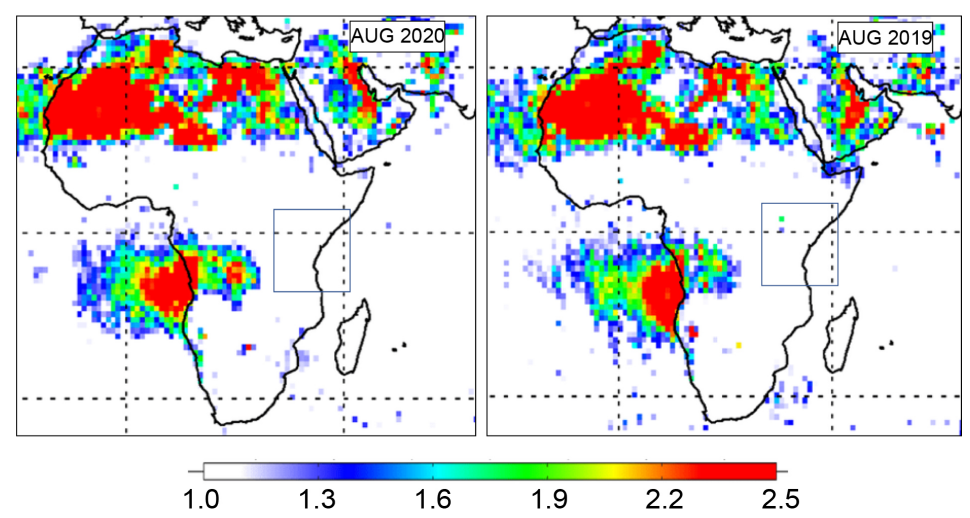

(h) 


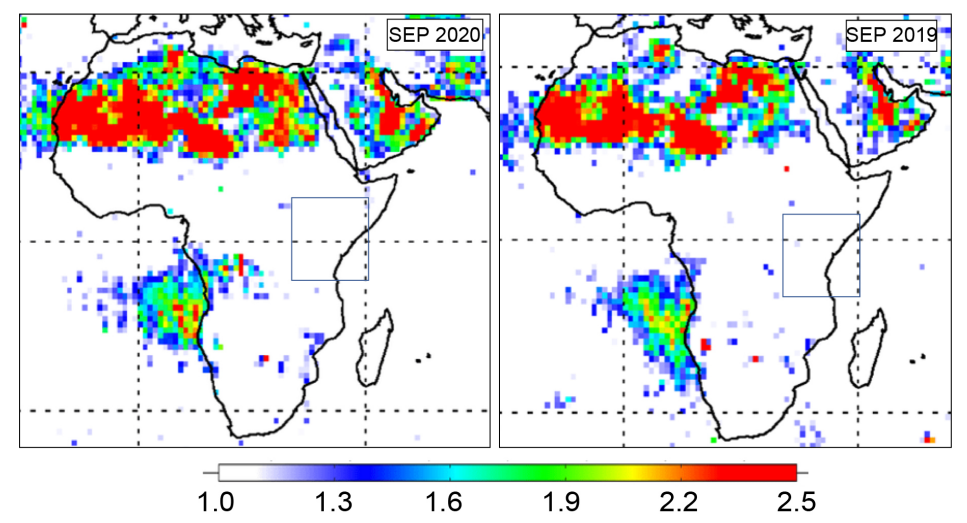

(i)
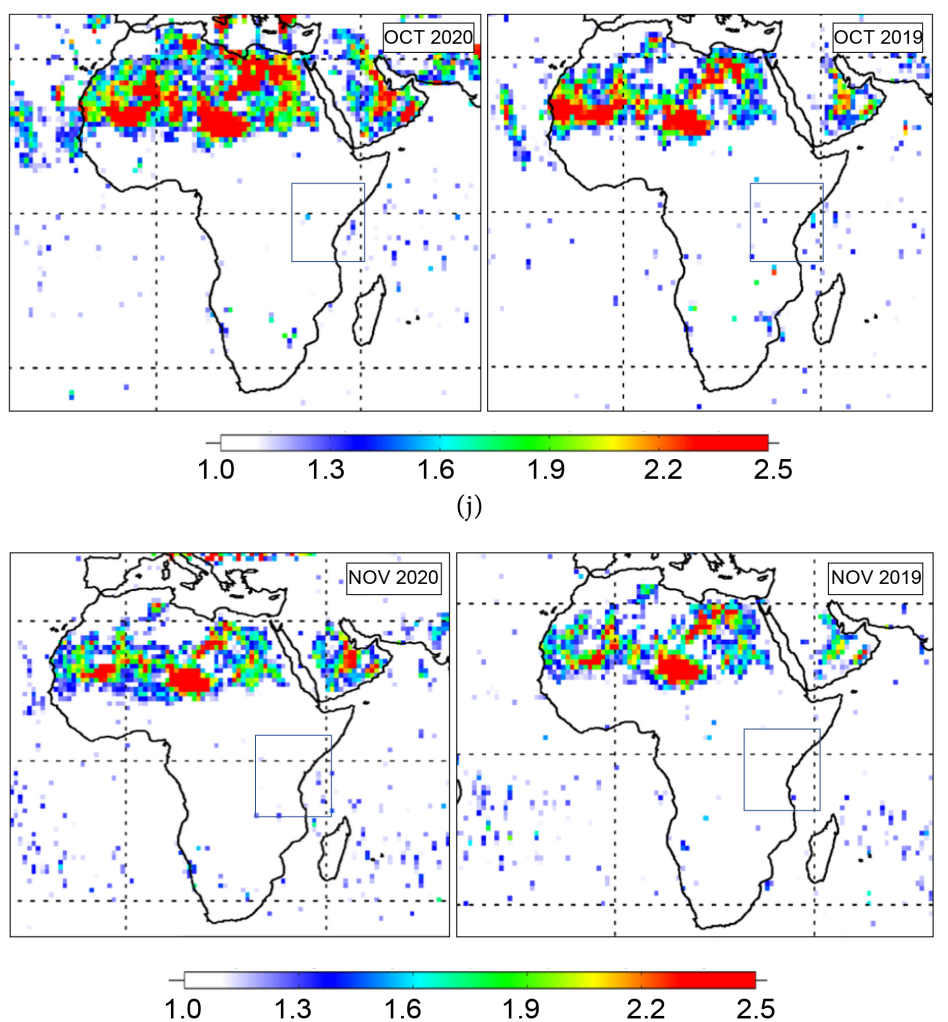

(k)

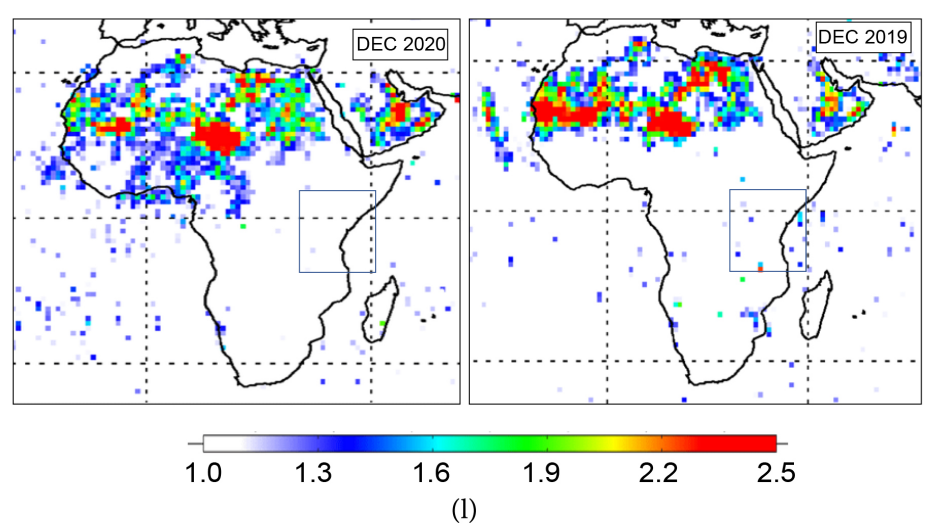

Figure 5. OMI/AURA Africa's Absorbing Aerosol Index for the year 2020 and baseline (2019). East Africa is focused with the square box. 
Egypt [15], Rio de Janeiro and Sao Paulo, Brazil [39] [40], China [17] [55], India [37], Milan [45], Barcelona [42], Nice, Rome, Valencia and Turin [43]. The PM emissions in Kampala, Nairobi and Dar es Salaam has increasingly surpassed WHO regulatory guidelines in both $\mathrm{PM}_{10}$ and $\mathrm{PM}_{2.5}$ size ranges [20] [34] [35] [47] [56]-[64]. Thus, there is need to tighten the air quality guidelines to maintain the air quality levels.

\section{Conclusion}

COVID-19 has been a crisis that has led to the undermining of environmental priorities and the realization of some Sustainable Development Goals. It has been visualized as a prelude to a looming future climate crisis, yet reports have also indicated that lockdowns imposed as a COVID-19 containment measure worldwide have led to improvement in air quality in various regions. The paucity of published reports or systematic and regulatory grade measurements of air pollution in East African cities prompted the current study. The results indicated that the imposed lockdowns in Kampala and Nairobi cities led to reductions in $\mathrm{NO}_{2}$ emissions by $6.0 \%$ and $8.91 \%$, while the AAI decreased by about $1.91 \%$ for the year 2020. Dar es Salaam recorded a $1.16 \%$ increase in $\mathrm{NO}_{2}$ emissions though the AAI remained almost constant in 2020. The interim pollution reduction witnessed during the COVID-19 lockdown in Uganda and Kenya indicates that the region needs stimulus packages that prioritize low-carbon approaches in the post-pandemic era, with a shift to both clean and renewable energy. We recommend the installation of continuous air pollution monitoring centers within the region so as to provide data for evidentiary comparison of air pollution levels.

\section{Acknowledgements}

The authors are grateful to the World Bank and the Inter-University Council of East Africa (IUCEA) for the scholarship awarded to Timothy Omara through the Africa Center of Excellence II in Phytochemicals, Textiles and Renewable Energy (ACE II PTRE) at Moi University (Kenya) which made this study possible. The analyses and visualizations presented in this study were from online data systems developed and maintained by NASA to which we are grateful. The NASA team is highly acknowledged for compiling data on air pollutants during the pandemic year of 2020 .

\section{Conflicts of Interest}

The authors declare no conflicts of interest regarding the publication of this paper.

\section{References}

[1] Muhammad, S., Long, X. and Salman, M. (2020) COVID-19 Pandemic and Environmental Pollution: A Blessing in Disguise? Science of the Total Environment, 728, Article ID: 138820. https://doi.org/10.1016/j.scitotenv.2020.138820 
[2] Machhi, J., Herskovitz, J., Senan, A.M., Dutta, D., Oleynikov, M.D., et al. (2020) The Natural History, Pathobiology, and Clinical Manifestations of SARS-CoV-2 Infections. Journal of Neuroimmune Pharmacology, 153, 359-386. https://doi.org/10.1007/s11481-020-09944-5

[3] Guo, Y.R., Cao, Q.D., Hong, Z.S., Tan, Y.Y., Jin, H.J., et al. (2020) The Origin, Transmission and Clinical Therapies on Coronavirus Disease 2019 (COVID-19) Outbreak-An Update on the Status. Military Medical Research, 7, Article No. 11. https://doi.org/10.1186/s40779-020-00240-0

[4] Hadisi, Z., Walsh, T., Dabiri, S.M.H., Seyfoori, A., Hamdi, D., Mirani, B., et al. (2020) Management of Coronavirus Disease 2019 (COVID-19) Pandemic: From Diagnosis to Treatment Strategies. Advanced Therapeutics, 4, Article ID: 2000173. https://doi.org/10.1002/adtp.202000173

[5] World Health Organization (2020) WHO Director-General's Opening Remarks at the Mediabriefing on COVID-19. March 11, 2020.

[6] World Health Organization (2021) WHO Coronavirus Disease (COVID-19) Dashboard.

https://covid19. who.int/?gclid=Cj0KCQiA2uH-BRCCARIsAEeef3mNi83o9BNiFZ2vfDgZgJPecO5Ga7CuZGN8RZ859LzUE5gEuaxqwMaAi_pEALw wcB

[7] Angom, J. (2021) Post-COVID-19 Scenarios in the East African Community: Implications for Sustainable Development. South Asian Journal of Social Studies and Economics, 10, 45-61. https://doi.org/10.9734/sajsse/2021/v10i130255

[8] Clarke International University (2021) Daily East African Update on COVID-19. https://ciu.ac.ug/news/daily-east-african-update-on-covid-19

[9] EAC (East African Community) (2020) EAC at A Glance. https://www.eac.int/

[10] Veefkind, P., Van Oss, R. F., Eskes, H., Borowiak, A., Dentner, F. and Wilson, J. (2007) The Applicability of Remote Sensing in the Field of Air Pollution. Institute for Environment and Sustainability, Ispra.

[11] Engel-Cox, J.A., Hoff, R.M. and Haymet, A.D.J. (2004) Recommendations on the Use of Satellite Remote-Sensing Data for Urban Air Quality. Journal of Air and Waste Management Association, 54, 1360-1371.

https://doi.org/10.1080/10473289.2004.10471005

[12] National Aeronautics and Space Administration (NASA) (2020) National Aeronautics and Space Administration. AURA OMI Average Tropospheric $\mathrm{NO}_{2}$ Maps, Airborne Nitrogen Dioxide Emission. https://so2.gsfc.nasa.gov/no2/no2 index.html

[13] National Aeronautics and Space Administration (NASA) (2020) Ozone Monitoring Instrument. https://aura.gsfc.nasa.gov/omi.html

[14] Somvanshi, S.S., Vashisht, A., Chandra, U. and Kaushik, G. (2019) Delhi Air Pollution Modeling Using Remote Sensing Technique. In: Hussain, C.M., Ed., Handbook of Environmental Materials Management, Springer, Switzerland, 1-27. https://doi.org/10.1007/978-3-319-58538-3 174-1

[15] Mostafa, M.K., Gamal, G. and Wafiq, A. (2021) The Impact of COVID 19 on Air Pollution Levels and Other Environmental Indicators-A Case Study of Egypt. Journal of Environmental Management, 277, Article ID: 111496. https://doi.org/10.1016/j.jenvman.2020.111496

[16] TEMIS (2020) OMI/AURA Absorbing Aerosol Index. http://www.temis.nl/airpollution/absaai/

[17] Wang, Q. and Su, M. (2020) A Preliminary Assessment of the Impact of COVID-19 on Environment-A Case Study of China. Science of the Total Environment, 728, 
138915. https://doi.org/10.1016/j.scitotenv.2020.138915

[18] Dentons (2020) Covid-19: Possible Approaches to Managing Employee-Employer Relations.

https://www.dentons.com/en/insights/articles/2020/april/16/covid-19-possible-appr oaches-to-managing-employee-employer-relations

[19] Anguyo, I. and Storer, L. (2020) In Times of COVID-19 Kampala Has Become 'un-Ugandan'.

https://blogs.lse.ac.uk/africaatlse/2020/04/09/kampala-epidemic-un-ugandan-societ y-in-times-covid-19/

[20] AirQo (2020) Kampala Air Quality Improves by up to $40 \%$ during the Covid-19 lockdown.

https://www.airqo.net/blog-post/14221308-kampala-air-quality-improves-by-up-to40-during-the-covid19-lockdown

[21] Calvin-Smith, G. (2020) Covid-19: Uganda Extends Lockdown for Two Weeks but Slowly Eases Measures.

https://www.france24.com/en/africa/20200505-uganda-extends-lockdown-for-twoweeks-but-slowly-eases-measures

[22] Garda World (2020) Uganda: Authorities Ease Certain Restrictions and Extend Lockdown by 14 Days May 4 /Update 6.

https://www.garda.com/crisis24/news-alerts/339056/uganda-authorities-ease-certai n-restrictions-and-extend-lockdown-by-14-days-may-4-update-6

[23] Mwangi, N. (2020) Uganda to Start Easing Virus Lockdown from June 2. https://africa.cgtn.com/2020/05/19/uganda-to-start-easing-virus-lockdown-from-ju $\underline{\text { ne-2l }}$

[24] Uganda Media Center (2020) President Musevenis 8th Address on COVID 19 and Lockdown Relaxation.

https://www.mediacentre.go.ug/media/president-musevenis-8th-address-covid-19-a nd-lockdown-relaxation

[25] Xinhua (2020) Kenyans Ready for Partial Lifting of COVID-19 Restrictions. http://www.xinhuanet.com/english/2020-06/05/c 139114874.htm

[26] Garda World (2020) Kenya: Authorities Announce Extension of Lockdown Measures until July $6 /$ Update 23.

https://www.garda.com/crisis24/news-alerts/348946/kenya-authorities-announce-ex tension-of-lockdown-measures-until-july-6-update-23

[27] Mules, I. (2020) Tanzania under Fire from WHO for Lackluster Response to COVID-19 Pandemic.

https://www.dw.com/en/tanzania-under-fire-from-who-for-lackluster-response-tocovid-19-pandemic/a-53304699

[28] Vuzo, S. (2020) How COVID-19 Is Changing the Lives of Tanzanians. https://www.un.org/africarenewal/web-features/coronavirus/how-covid-19-changin g-lives-tanzanian

[29] Izugbara, C., Schaub, E., Bhatti, A., Marlow, H., Anderson, E. and Hinson, L. (2021) COVID-19 and Indigenous Women in East Africa: Emerging Impacts, Responses and Opportunities. International Center for Research on Women, Washington DC.

[30] Kell, F. (2020) Tanzania Evades COVID-19 Lockdown, but Restrictions Persist. https://www.chathamhouse.org/2020/05/tanzania-evades-covid-19-lockdown-restri ctions-persist

[31] Google (2021) COVID-19 Community Mobility Report-Uganda. https://www.gstatic.com/covid19/mobility/2021-01-19 UG Mobility Report en-G 
B.pdf

[32] Google (2021) COVID-19 Community Mobility Report-Kenya. https://www.gstatic.com/covid19/mobility/2021-01-19 KE Mobility Report en-G B.pdf

[33] Mbuligwe, S.E. and Kassenga, G.R. (1997) Automobile Air Pollution in Dar es Salaam City, Tanzania. Science of the Total Environment, 199, 227-235. https://doi.org/10.1016/S0048-9697(97)05461-2

[34] International Association for Medical Assistance to Travellers (IAMAT)(2020) Tanzania General Health Risks: Air Pollution. International Association for Medical Assistance to Travellers, Toronto.

https://www.iamat.org/country/tanzania/risk/air-pollution\#

[35] Jackson, M.M. (2005) Roadside Concentration of Gaseous and Particulate Matter Pollutants and Risk Assessment in Dar-es-Salaam, Tanzania. Environmental Monitoring and Assessment, 104, 385-407. https://doi.org/10.1007/s10661-005-1680-y

[36] Gautam, S. (2020) Covid-19: Air Pollution Remains Low as People Stay at Home. Air Quality, Atmosphere and Health, 13, 853-857.

https://doi.org/10.1007/s11869-020-00842-6

[37] Sharma, S., Zhang, M., Anshika, Gao, J., Zhang, H. and Kota, S.H. (2020) Effect of Restricted Emissions during COVID-19 on Air Quality in India. Science of the Total Environment, 728, Article ID: 138878. https://doi.org/10.1016/j.scitotenv.2020.138878

[38] Anil, I. and Alagha, O. (2021) The Impact of COVID-19 Lockdown on the Air Quality of Eastern Province, Saudi Arabia. Air Quality, Atmosphere and Health, 14, 117-128. https://doi.org/10.1007/s11869-020-00918-3

[39] Dantas, G., Siciliano, B., França, B.B., da Silva, C.M. and Arbilla, G. (2020) The Impact of COVID-19 Partial Lockdown on the Air quality of the City of Rio de Janeiro, Brazil. Science of the Total Environment, 729, Article ID: 139085. https://doi.org/10.1016/j.scitotenv.2020.139085

[40] Nakada, L.Y.K. and Urban, R. C. (2020) COVID-19 pandemic: Impacts on the Air quality during the Partial Lockdown in São Paulo State, Brazil. Science of the Total Environment, 729, Article ID: 139087. https://doi.org/10.1016/j.scitotenv.2020.139087

[41] Jakovljević, I., Štrukil, Z.S., Godec, R., Davila, S. and Pehnec, G. (2020) Influence of Lockdown Caused by the COVID-19 Pandemic on Air Pollution and Carcinogenic Content of Particulate Matter Observed in Croatia. Air Quality, Atmosphere \& Health, 14, 467-472. https://doi.org/10.1007/s11869-020-00950-3

[42] Tobías, A., Carnerero, C., Reche, C., Massagué, J., Via, M., Minguill'on, M.C., et al. (2020) Changes in Air Quality during the Lockdown in Barcelona (Spain) One Month into the SARS-CoV-2 Epidemic. Science of the Total Environment, 726, Article ID: 138540. https://doi.org/10.1016/j.scitotenv.2020.138540

[43] Sicard, P., Marco, A.D., Agathokleous, E., Feng, Z., Xu, X., Paoletti, E., et al. (2020) Amplified Ozone Pollution in Cities during the COVID-19 Lockdown. Science of the Total Environment, 735, Article ID: 139542. https://doi.org/10.1016/j.scitotenv.2020.139542

[44] Donzelli, G., Cioni, L., Cancellieri, M., Morales, A.L. and Suárez-Varela, M.M.M. (2020) The Effect of the Covid-19 Lockdown on Air Quality in Three Italian Medium-Sized Cities. Atmosphere, 11, Article No. 1118.

https://doi.org/10.3390/atmos11101118

[45] Collivignarelli, M.C., Abbà, A., Bertanza, G., Pedrazzani, R., Ricciardi, P. and Miino, 
M.C. (2020) Lockdown for CoViD-2019 in Milan: What Are the Effects on Air Quality? Science of the Total Environment, 732, Article ID: 139280. https://doi.org/10.1016/j.scitotenv.2020.139280

[46] Goldberg, D.L., Anenberg, S.C., Griffin, D., McLinden, C.A., Lu, Z. and Streets, D.G. (2020) Disentangling the Impact of the COVID-19 Lockdowns on Urban $\mathrm{NO}_{2}$ from Natural Variability. Geophysics Research Letters, 47, Article ID: e2020GL089269. https://doi.org/10.1002/essoar.10503396.1

[47] Singh, A., Pope, F. and Avis W.R. (2020) Visibility as a Proxy for Air Quality in East Africa. Environmental Research Letters, 15, Article ID: 084002. https://doi.org/10.1088/1748-9326/ab8b12

[48] Abnett, K. (2020) China Sees Post-lockdown Rise in Air Pollution: Study. https://www.reuters.com/article/us-health-coronavirus-china-pollution/china-seespost-lockdown-rise-in-air-pollution-study-idUSKBN22U09F

[49] Okure, D., Bainomugisha, E., Lozano-Gracia, N. and Soppelsa, M.E. (2021) Characterization of Ambient Air Quality in Selected Urban Areas in Uganda: A Low-Cost Approach. Policy Research Working Paper No. 9512, World Bank, Washington DC. https://doi.org/10.1596/1813-9450-9512

[50] Ngo, N. S., Gatari, M., Yan, B., Chillrud, S.N., Bouhamam, K. and Kinney, P.L. (2015) Occupational Exposure to Roadway Emissions and Inside Informal Settlements in Sub-Saharan Africa: A Pilot Study in Nairobi, Kenya. Atmospheric Environment, 111, 179-184. https://doi.org/10.1016/j.atmosenv.2015.04.008

[51] Dasgupta, S., Lall, S. and Wheeler, D. (2020) Traffic, Air Pollution, and Distributional Impacts in Dar es Salaam: A Spatial Analysis with New Satellite Data. Policy Research Working Paper No. 9185, World Bank, Washington DC. https://doi.org/10.1596/1813-9450-9185

[52] Heger, M., Wheeler, D., Zens, G. and Meisner, C. (2019) Motor Vehicle Density and Air Pollution in Greater Cairo: Fuel Subsidy Removal and Metro Line Extension \& Their Effect Congestion and Pollution? The World Bank, Washington DC. https://doi.org/10.1596/32512

[53] Abbass, R.A., Kumar, P. and El-Gendy, A. (2020) Car User's Exposure to Particulate Matter and Gaseous Air Pollutants in Megacity Cairo. Sustainable Cities and Society, 56, Article ID: 102090. https://doi.org/10.1016/j.scs.2020.102090

[54] Rajé, F., Tight, M. and Pope, F.D. (2018) Traffic Pollution: A Search for Solutions for a City Like Nairobi. Cities, 82, 100-107. https://doi.org/10.1016/j.cities.2018.05.008

[55] Wang, P., Chen, K., Zhu, S., Wang, P. and Zhang, H. (2020) Severe Air Pollution Events Not Avoided by Reduced Anthropogenic Activities during COVID-19 Outbreak. Resources Conservation and Recycling, 158, Article ID: 104814. https://doi.org/10.1016/j.resconrec.2020.104814

[56] Pope, F.D., Gatari, M., Ng'ang'a, D., Poynter, A. and Blake, R. (2018) Airborne Particulate Matter Monitoring in Kenya Using Calibrated Low-Cost Sensors. Atmospheric Chemistry and Physics, 18, 15403-15418.

https://doi.org/10.5194/acp-18-15403-2018

[57] Schwander, S., Okello, C.D., Freers, J., Chow, J.C., Watson, J.G., Corry, M. and Meng, Q. (2014) Ambient Particulate Matter Air Pollution in Mpererwe District, Kampala, Uganda: A Pilot Study. Journal of Environmental and Public Health, 2014, Article ID: 763934. https://doi.org/10.1155/2014/763934

[58] Kirenga, B. J., Meng, Q., van Gemert, F., Aanyu-Tukamuhebwa, H., Chavannes, N., Katamba, A., et al. (2015) The State of Ambient Air Quality in Two Ugandan Cities: 
A Pilot Cross-Sectional Spatial Assessment. International Journal of Environmental Research and Public Health, 12, 8075-8091. https://doi.org/10.3390/ijerph120708075

[59] Egondi, T., Muindi, K., Kyobutungi, C., Gatari, M. and Rocklöv, J. (2016) Measuring Exposure Levels of Inhalable Airborne Particles $\left(\mathrm{PM}_{2.5}\right)$ in Two Socially Deprived Areas of Nairobi, Kenya. Environmental Research, 148, 500-506. https://doi.org/10.1016/j.envres.2016.03.018

[60] Gaita, S.M., Boman, J., Gatari, M.J., Pettersson, J.B.C. and Janhäll, S. (2014) Source Apportionment and Seasonal Variation of $\mathrm{PM}_{2.5}$ in a Sub-Saharan African City: Nairobi, Kenya. Atmospheric Chemistry and Physics, 14, 9977-9991. https://doi.org/10.5194/acp-14-9977-2014

[61] Egondi, T., Ettarh, R., Kyobutungi, C., Ng, N. and Rocklöv, J. (2018) Exposure to Outdoor Particles $\left(\mathrm{PM}_{2.5}\right)$ and Associated Child Morbidity and Mortality in Socially Deprived Neighborhoods of Nairobi, Kenya. Atmosphere, 9, Article No. 351. https://doi.org/10.3390/atmos9090351

[62] West, S.E., Büker, P., Ashmore, M., Njoroge, G., Welden, N., Muhoza, C., et al. (2020) Particulate Matter Pollution in an Informal Settlement in Nairobi: Using Citizen Science to Make the Invisible Visible. Applied Geography, 114, Article ID: 102133. https://doi.org/10.1016/j.apgeog.2019.102133

[63] Muindi, K. (2017) Air Pollution in Nairobi Slums: Sources, Levels and Lay Perceptions. Doctoral Thesis, Umeå University, Faculty of Medicine, Department of Public Health and Clinical Medicine, Epidemiology and Global Health, Nairobi, Kenya.

[64] Koleleni, Y.I.A. (2002) Environmental Air Degradation in Dar es Salaam by X-Ray Fluorescence. Journal of Environmental Science and Health, Part A, 37, 385-398. https://doi.org/10.1081/ESE-120002836 